\title{
The Loma de Hierro Ni-laterite deposit (Venezuela): Mineralogical and chemical composition
}

\section{El depósito de lateritas Ni de Loma de Hierro (Venezuela): Composición química y mineralógica}

\author{
Cristina Domènech ${ }^{1, *}$, Salvador Galín ${ }^{2}$, Josep M. Soler ${ }^{3}$, Marite P. Ancco², Williams Meléndez ${ }^{4}$, \\ José Rondón ${ }^{5}$, Cristina Villanova-de-Benavent ${ }^{2}$, Joaquín A. Proenza ${ }^{2}$
}

\begin{abstract}
Grup MAiMA, Mineralogia Aplicada, Geoquímica i Geomicrobiologia, Departament de Mineralogia, Petrologia i Geologia Aplicada, Facultat de Ciències de la Terra, Universitat de Barcelona (UB), Martí i Franquès s/n, 08028 Barcelona, Catalunya, Spain.
\end{abstract}

Departament de Mineralogia, Petrologia i Geologia Aplicada, Facultat de Ciències de la Terra, Universitat de Barcelona (UB), Martí i Franquès s/n, 08028 Barcelona, Catalunya, Spain.

${ }^{3}$ Institute of Environmental Assessment and Water Research, IDAEA-CSIC, 08034 Barcelona, Catalunya, Spain.

${ }^{4}$ Instituto de Ciencias de la Tierra, Universidad Central de Venezuela, Av. Minerva, 1015, Caracas,Venezuela.

${ }^{5}$ Instituto Nacional de Geología y Minería, Av. Lecuna, Parque Central, Torre Oeste,1015, Caracas, Venezuela.

* Corresponding author: (C. Domènech) cristina.domenech@ub.edu

\section{How to cite this article:}

Domènech, C., Galí, S., Soler, J. M., Ancco, M. P., Meléndez, W., Rondón, J., Villanova-deBenavent, G., Proenza, J. A., 2020, The Loma de Hierro Ni-laterite deposit (Venezuela): Mineralogical and chemical composition: Boletín de la Sociedad Geológica Mexicana, 72 (3), A050620. http://dx.doi.org/10.18268/ BSGM2020v72n3a050620

Manuscript received: October 21, 2019

Corrected manuscript received: June 2, 2020 Manuscript accepted: June 20, 2020

Peer Reviewing under the responsibility of Universidad Nacional Autónoma de México.

This is an open access article under the CC BY-NC-SA license(https://creativecommons.org/licenses/by-nc-sa/4.0/)

\section{ABSTRACT}

Nickel laterite deposits developed on ultramafic rocks have traditionally been a significant source of $\mathrm{Ni}$ and Co and recently of Sc. Although the Loma de Hierro deposit (Venezuela) has been in operation for more than 50 years, it lacks detailed studies on the mineralogical and geochemical composition of the lateritic profile. In this study, we present a geochemical and mineral description of the main carrier phases of $\mathrm{Ni}$ and $\mathrm{Co}$ in a complete profile of the deposit. The selected weathering profile has been developed from a partially serpentinized harzburgitic protolith and has a well-developed saprolitic horizon covered by a thin limonitic horizon. The geochemical signature of the profile is characterized by a significant $\mathrm{Mg}$ and $\mathrm{Si}$ decrease towards the top of the saprolite, with a clearly visible $\mathrm{Mg}$ discontinuity. The main Ni-bearing minerals are secondary serpentine $(1-4 \mathrm{wt} . \% \mathrm{NiO})$ and kerolite-pimelite-dominated garnierite mixtures with serpentine (18-22 wt.\% NiO). Limonite is rich in goethite $(0-1.85$ wt. $\% \mathrm{NiO})$, gibbsite, and Mn-oxy-hydroxides. The latter have intermediate compositions between lithiophorite and asbolane (2-13 wt. $\% \mathrm{CoO})$. The highest Sc grades $(40-68 \mathrm{ppm})$ were observed in the limonite with amounts positively correlated with $\mathrm{Fe}$ content. Rare earth elements are mainly concentrated in the upper part of the saprolite horizon (60-80 ppm), while they have a lower content in the limonite $(7-45 \mathrm{ppm})$. In this horizon, rare earth elements are clearly associated with $\mathrm{Fe}$, indicating adsorption and/ or coprecipitation. This association was not observed in the saprolite, suggesting that other minerals (e.g., clay minerals) are controlling their concentration; more information is needed to identify the rare earth element-bearing minerals. The lateritic profile of Loma de Hierro can be classified as representative of hydrated $\mathrm{Mg}$ silicate deposits, and was formed in a context of continuous tectonic uplift and a low water table conditions favoring the development of a thick saprolitic horizon and the precipitation of kerolite-pimelite-dominated garnierites.

Keywords: Nickel, cobalt, Loma de Hierro, laterite, critical metals.

\section{RESUMEN}

Los depósitos lateríticos desarrollados sobre rocas ultra máficas han sido tradicionalmente una fuente significativa de Niy Co y recientemente de Sc. Aunque el depósito de Loma de Hierro (Venezuela) ha estado más de 50 años en explotación, adolece de estudios detallados sobre la composición mineralógica y geoquímica del perfil laterítico. En este estudio presentamos una descripción geoquímica y mineralógica, incluyendo las principales fases portadoras de Ni y $\mathrm{Co}$, de un perfil completo de este depósito. El perfil se ha desarrollado a partir de un protolito harzburgítico parcialmente serpentinizado. Presenta un horizonte saprolítico bien desarrollado cubierto por un delgado horizonte limonítico. El Mg y Si disminuyen hacia la parte superior de la saprolita y la discontinuidad de $\mathrm{Mg}$ se identifica claramente. Los principales minerales portadores de $\mathrm{Ni}$ son serpentina secundaria (1-4\% en peso $\mathrm{NiO}$ ) y garnieritas con una composición de mezcla entre kerolita-pimelita y serpentina en menor medida $(18-22 \%$ en peso $\mathrm{NiO})$. La limonita es rica en goethita (0-1.9\% en peso $\mathrm{NiO})$, gibbsita y oxihidróxidos de $\mathrm{Mn}$, de composición intermedia entre litioforita y asbolana (2-13\% en peso $\mathrm{CoO}$ ). Las concentraciones más elevadas de Sc (40-60 ppm) se encuentran en la limonita y se correlacionan positivamente con los contenidos en Fe. Los elementos de tierras raras se concentran principalmente en la parte superior del horizonte de saprolita (60-80 ppm) y la limonita tiene un contenido menor (7-45 ppm). En este horizonte, los elementos de las tierras raras están claramente asociados al Fe (adsorción/coprecipitación), asociación que no se observa en la saprolita, lo que sugiere que otros minerales controlan su concentración. El perfil laterítico de Loma de Hierro se puede clasificar como representativo de depósitos tipo silicato de $\mathrm{Mg}$ hidratado. Se formó en un contexto de levantamiento tectónico continuo y un nivel freático bajo, condiciones que favorecieron el desarrollo de un horizonte saprolitico de gran espesor y la precipitación de las garnieritas dominadas por kerolita-pimelita.

Palabras clave: Níquel, Cobalto, Loma de Hierro, laterita, metales críticos. 


\section{Introduction}

Nickel laterite deposits are an important source of $\mathrm{Ni}$ and Co (Golightly, 1981, 2010; Freyssinet et al., 2005; Lambiv Dzemua et al., 2013), and are also considered worthy targets for Sc and platinum-group-element (PGE) exploration (Aiglsperger et al., 2016; Chassé et al. 2017, 2019; Teitler et al., 2019 and references therein).

Worldwide, the estimated land-based resources of nickel are about 150-300 Mtons, 40\% of which are found in magmatic sulfide deposits, and 60\% in laterites (Gleeson et al., 2003; Kuck, 2013). Ni-laterite deposits are mainly found in New Caledonia, Indonesia, the Philippines, Australia, Brazil, and the Caribbean area. The global mine production of $\mathrm{Ni}$ has greatly increased in the period 2000-2018, reaching values close to 2.5 Mtons in 2015 (McRae, 2018) due to the increasing demand in China and other countries, which has been covered by the main $\mathrm{Ni}$ producers in Russia, Australia, Indonesia, Canada, New Caledonia, the Philippines, and Brazil.
Ni-laterite deposits form from the chemical and mechanical weathering of partially or totally serpentinized ultramafic rocks (dunites, harzburgites), exposed to the surface under favorable climatic and topographic conditions. Their formation is controlled by intrinsic factors (protolith chemical and mineralogical composition, mineral dissolution rates, and surface areas) and by extrinsic factors (geological and hydrological context, temperature and rainfall, weathering process duration; e.g., Freyssinet et al., 2005; Butt and Cluzel, 2013).

A typical Ni-laterite profile consists of a set of superposed horizons over a partially or totally serpentinized ultramafic rock (protolith). The profile is comprised of unaltered minerals at the bottom, followed by a saprolite horizon dominated by secondary $\mathrm{Si}$ - and $\mathrm{Mg}$-bearing minerals with textural features inherited from the protolith, and a limonite horizon at the top. The limonite horizon is composed mainly by goethite that evolves to hematite with time (Golightly, 1981, 2010).

During the ore-formation process triggering lateritization, the interaction of slightly acidic mete-

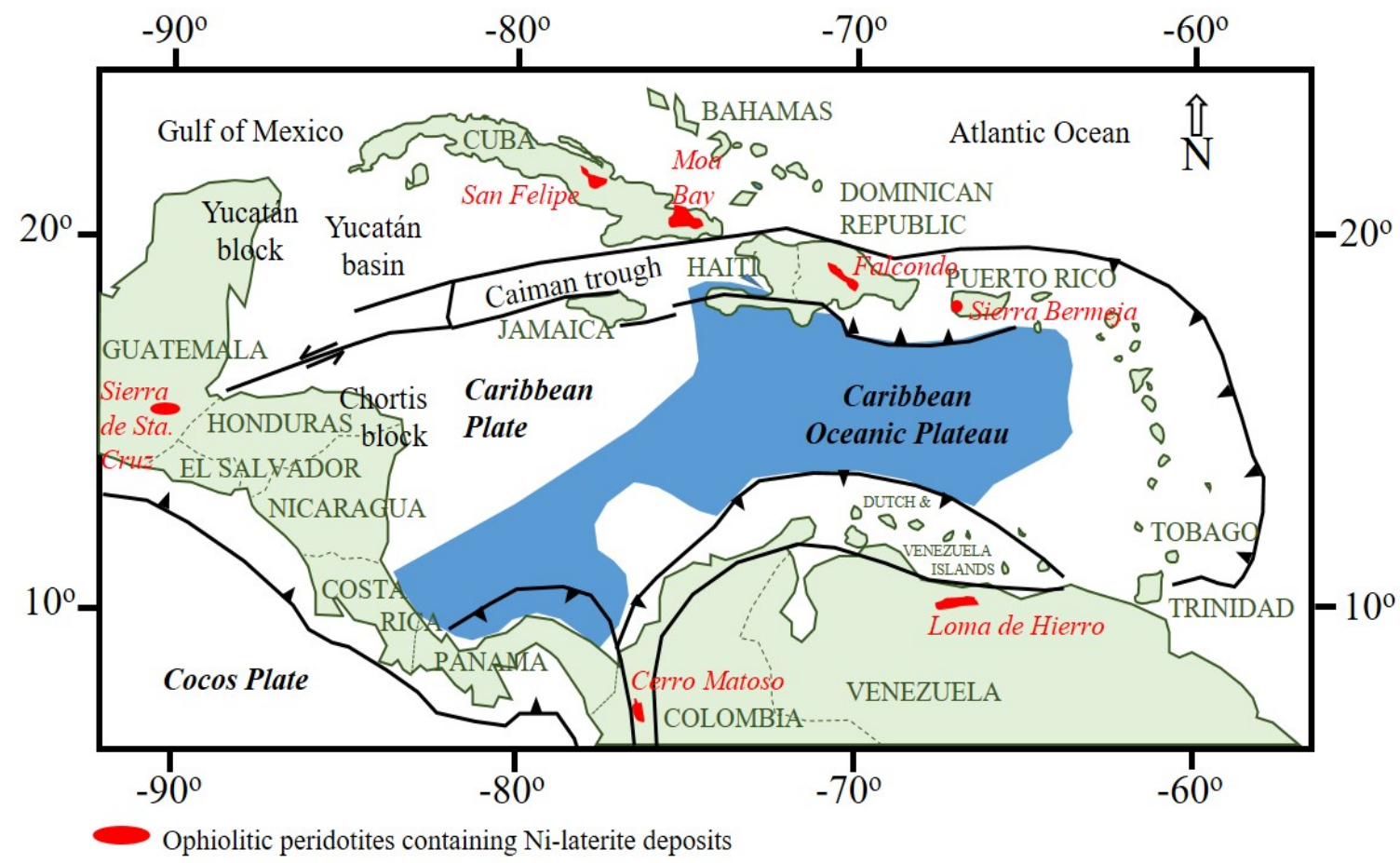

Figure 1 Distribution of ophiolitic peridotites containing Ni-laterite deposits around the margins of the Caribbean Plate. Ni-laterite deposits from Moa Bay and San Felipe (Cuba), Falcondo (Dominican Republic), Sierra Bermeja (Puerto Rico), Loma de Hierro (Venezuela), Cerro Matoso (Colombia) and Sierra de Santa Cruz (Guatemala). Modified from Lewis et al. (2006) and Aiglsperger et al. (2016). 
oric waters with the ultramafic protolith causes the release of $\mathrm{Mg}$ and $\mathrm{Si}$, which are transported downwards. In the limonite zone, $\mathrm{Ni}$ is mainly retained by goethite (adsorbed or substituting Fe in the mineral structure) and by minor Mn-oxy-hydroxides (Roqué-Rosell et al., 2010; Dublet et al., 2015 and references therein). With time $\mathrm{Ni}$ is remobilized and redeposited at depth. In the saprolite zone, $\mathrm{Ni}$ is mainly found in garnierite (e.g., Wells et al., 2009; Villanova-de-Benavent et al., 2014; Cathelineau et al., 2016) and/or secondary Ni-rich serpentine (e.g., Golightly and Arancibia, 1979; Pelletier, 1996; Villanova-de-Benavent et al., 2017) and smectite (e.g., Tauler et al., 2017; Putzolu et al., 2020).

Ni-laterites are usually classified into three categories according to their dominant Ni-bearing mineralogy. Oxide laterite deposits are those in which $\mathrm{Ni}$ is mainly associated with $\mathrm{Fe}$ - and Mn-oxy-hydroxides (e.g., goethite and lithiophorite-asbolane, respectively); clay silicate deposits are dominated by Ni-rich smectites; and hydrous $\mathrm{Mg}$ silicate deposits mainly have $\mathrm{Mg}-\mathrm{Ni}$ phyllosilicates (including garnierites; Brand et al., 1998; Freyssinet et al., 2005). Hydrous Mg silicate deposits generally have the highest $\mathrm{Ni}$ grades $(1.8-2.5$ wt. $\% \mathrm{Ni})$ and are characterized by a thick serpentine-dominated saprolite horizon covered by a thin limonite horizon. $\mathrm{Ni}$ mean grades in oxide-type deposits range from 1.0 to $1.6 \mathrm{wt.} \% \mathrm{Ni}$ (Butt and Cluzel, 2013 and references therein).

The main Ni-lateritic deposits discovered so far have developed in equatorial and tropical areas (latitude $\pm 26^{\circ}$; e.g., New Caledonia, Indonesia, Philippines, Cuba, Dominican Republic, Venezuela, Colombia, and Brazil). However, many laterite-endowed mineral districts (e.g., Greece, Urals, and Australia) also occur at higher latitudes and are generally classified as paleolaterites (Freyssinet et al., 2005). The petrography, mineralogy, and geochemistry of the most important Ni-laterite deposits situated in the northern part of the Caribbean plate (Cuba and Dominican Republic) have been recently revised and updated (e.g., Villanova-de-Benavent et al., 2014; Proenza, 2015; Aiglsperger et al., 2016; Domènech et al., 2017;
Roqué-Rosell et al., 2017; Tauler et al., 2017). In the southern margin, the most important deposits are in Colombia (Cerro Matoso) and Venezuela (Loma de Hierro; Figure 1).

Regarding the Venezuelan deposits, very few studies have been published, apart from the work of Soler et al. (2008). Recently, the technical shutdown of the Loma de Níquel exploitation and nickel production plant in Loma de Hierro (50 $\mathrm{km}$ SW of Caracas) opened the opportunity for collecting samples in a complete profile of an open pit, from the unaltered bedrock to the limonite at the top. The aim of this work is to gain further insight into the origin of Ni-laterite profile in the Loma de Hierro deposit. The present work reports a detailed petrographic, mineralogical, and geochemical description of the horizons, and the general mechanism of formation and enrichment in $\mathrm{Ni}$ is discussed taking into account the composition of the protolith and the role of climate, topography, elevation, and time of exposition.

\section{Geological setting}

\subsection{LOMA DE HIERRO Ni-LATERITE DEPOSIT}

The Loma de Hierro unit, where the mining area exists, is aligned $\mathrm{W}-\mathrm{E}$ and is part of an elongated, deformed belt in the southern Caribbean Plate margin (Figure 1; Lewis et al. 2006). The southern margin of the Caribbean Plate is represented by the late Cretaceous Dutch and Venezuelan Islands and the northern Cordilleras of Venezuela (Giunta et al., 2002a). Like the northern margin, the southern margin consists mainly of transpressive or strike-slip shear zones, and includes Jurassic to Cretaceous ophiolitic complexes cropping out along suture zones, such as that of Venezuela (Giunta et al., 2002b). This southern margin is formed by a thrust belt with a set of late Cretaceous south-vergent oceanic and continental tectonic units that have been progressively affected by brittle and ductile deformation related to $\mathrm{W}-\mathrm{E}$ strike-slip faults (e.g., La Victoria Fault, Figure 2; 


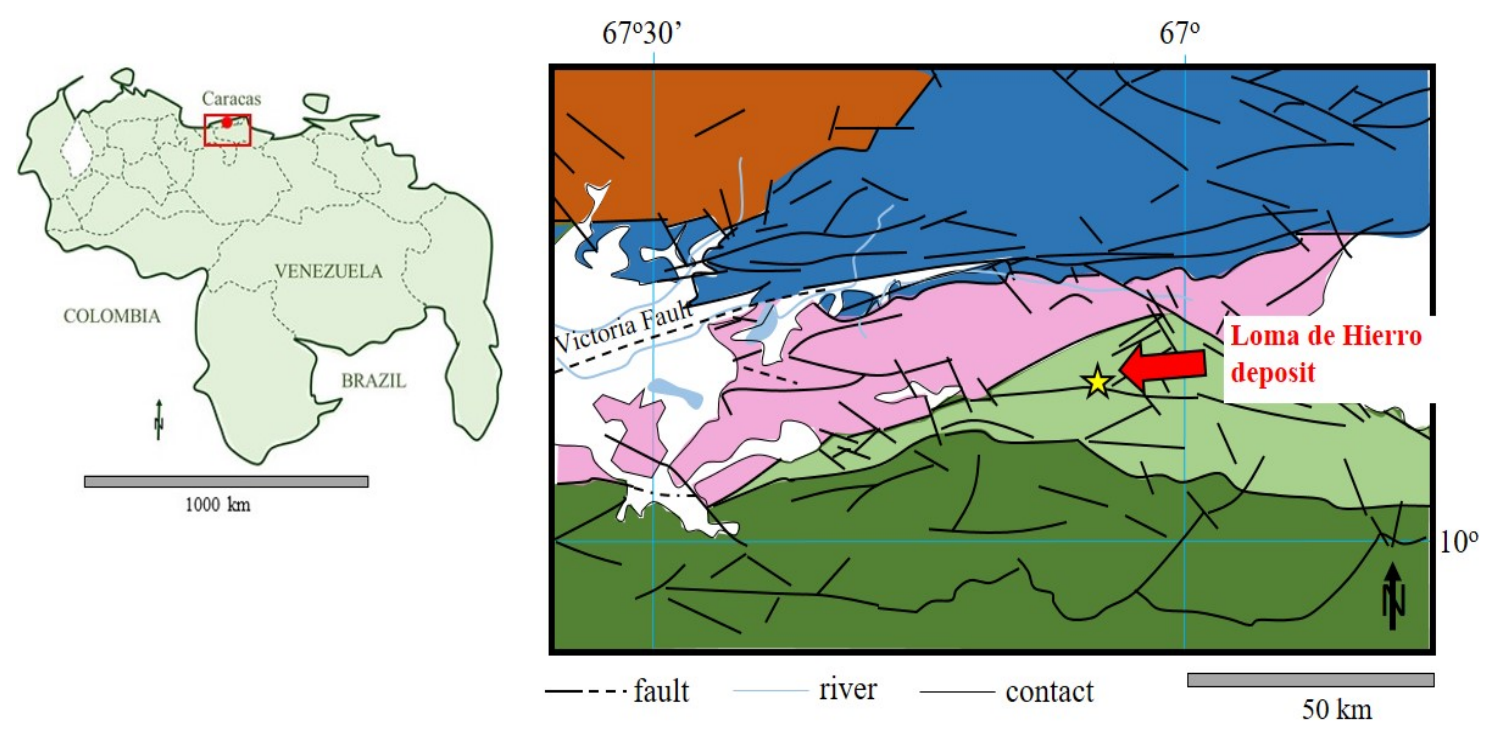

\section{UNITS}

Serranía de la Costa

Avila Unit (Ordovician $\rightarrow$ Permian)

Caracas Unit (Jurassic-Cretaceous)

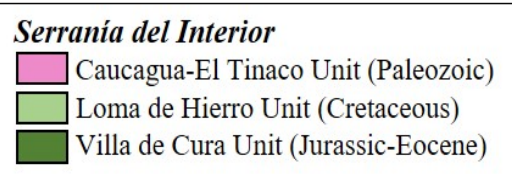

Figure 2 Simplified geological map of the study area showing the location of the Loma de Hierro laterite deposit. Simplified from Hackley et al. (2006).

Giunta et al., 2002b). The Franja-Costera unit (not shown in Figure 2), is an early Cretaceous ophiolitic mélange that overthrusts southwards the northern border of Serranía de la Costa (Giunta et al., 2002a). The Serranía de la Costa comprises the Paleozoic metamorphic association (orthogneisses and schists) of the Ávila unit (Urbani, 2005) and the late Jurassic carbonate-terrigenous sequences of the Caracas unit (Figure 2).

The Caucagua-El Tinaco unit, in the Serranía del Interior, overlies the Serranía de la Costa. It is a pre-Mesozoic basement covered by Cretaceous volcanosediments, basalts, dolerites, and gabbros (Figure 2; Giunta et al., 2002a). The Loma de Hierro unit appears to the south of the Caucagua-El Tinaco unit. It is an oceanic sequence of serpentinized mantle peridotites and Cretaceous metavolcanic sediments (Giunta et al., 2002a). The Loma de Hierro unit is overthrusted by the Villa del Cura unit, composed of early Cretaceous wehrlite-clinopyroxenite cumulates and metamorphosed serpentinized mantle peridotites, massive metabasalts and metavolcanic sediments (Giunta et al., 2002b).

\subsection{THE LOMA DE HIERRO Ni-LATERITE DEPOSIT}

The Ni-laterite deposit of Loma de Hierro is located $50 \mathrm{~km}$ SW of Caracas, in the northern-central part of the country, and extends roughly $\mathrm{W}-\mathrm{E}$ in a series of hills in the mountain ranges of Serranía del Interior. The area mined for nickel by the state company Loma de Níquel C.A. has a length of about $15 \mathrm{~km}$ with WSW-ENE direction, and a width from 1 to $7 \mathrm{~km}$, between the states of Aragua (west) and Miranda (east). Its coordinates are $10^{\circ} 09^{\prime} 10^{\circ} 10^{\prime} \mathrm{N}$ and $67^{\circ} 08^{\prime} 67^{\circ} 06^{\prime} \mathrm{W}$, and has an altitude of $\sim 1300$ m.a.s.l.

In 1941, laterite soils from Loma de Hierro were discovered as a potential source of nickel. They were exploited until 1960, when the work was stopped as the hills were declared an area of special natural interest. After several studies on the Ni-extraction economic interest and viability, exploitation was resumed in 2001 by Anglo American PLC. In 2015, the exploitation was assumed by the Venezuelan State, creating the company Loma de Níquel C.A., with an estimated reserve of 40 Mtons of nickel. In 2017, due to a technical 


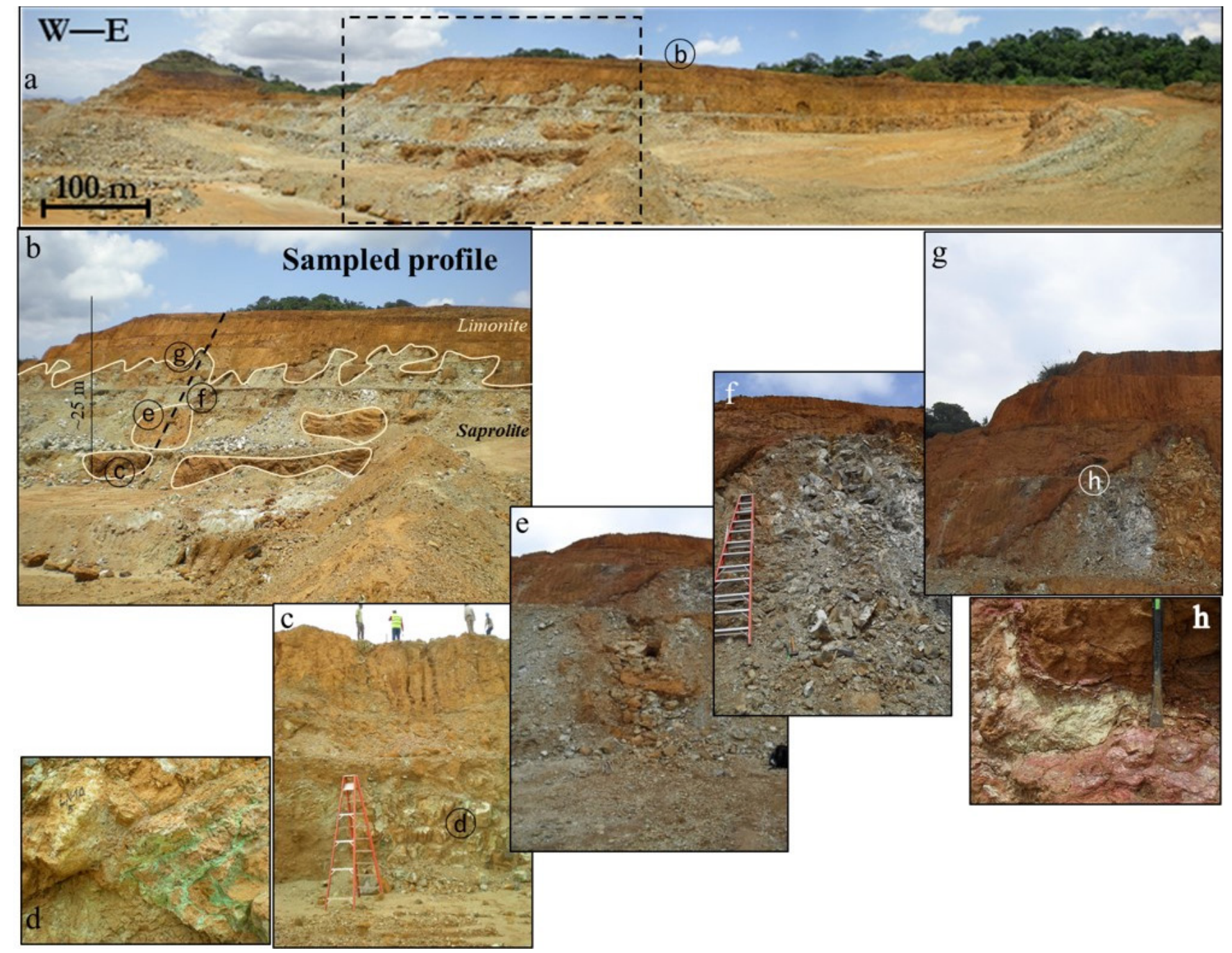

Figure 3 (a) Panoramic view of the laterite profile of Loma de Hierro, showing the location of the sampled area (b). (c) Detail of the lowest part of the profile, showing the sampled saprolite horizon (d). (e, f, g) Detail of the serpentine-dominated saprolite horizon. (h) Detail of the goethite-dominated limonite horizon.

shutdown of the exploitation and of the factory of ferronickel pellets attached to it, the mine could be visited, allowing the sampling of a complete laterite profile. A panoramic view and several details of the mining front are shown in Figure 3.

\section{Materials and analytical techniques}

\subsection{SAMPLING}

A total of 33 samples were collected from an exploitation front. The selected profile is $\sim 25 \mathrm{~m}$ thick and is characterized by three zones (from bottom to top): the serpentinised peridotite pro- tolith, a well-developed saprolite zone, and a thin limonite zone (Figure 3). For the present work, 17 of these samples were selected for detailed chemical and mineralogical analyses.

\subsection{ANALYTICAL AND GOMPUTATION TEGHNIQUES}

Samples were powdered, sieved below $75 \mu \mathrm{m}$ particle size, dried, and homogenized. Major, minor and trace element compositions were determined at the Actlabs Laboratories (Ontario, Canada) by $\mathrm{X}$-ray fluorescence (XRF) and inductively coupled plasma mass spectrometry (ICP-MS; after acid dissolution). 
Table 1. Concentrations of major and minor elements (in wt.\%) as well as of trace elements (in ppm) in samples from the Loma de Hierro laterite deposit.

\begin{tabular}{|c|c|c|c|c|c|c|c|c|c|c|c|c|c|c|c|c|c|}
\hline & \multicolumn{2}{|c|}{ Protolith } & \multicolumn{11}{|c|}{ Saprolite } & \multicolumn{4}{|c|}{ Limonite } \\
\hline & PR & A-01 & A-04 & A-08 & A-13 & A-14 & B-01 & B-03 & B-04-A & B-05 & B-07 & B-08 & B-10 & B-04-B & B-11 & B-12 & B-13/14 \\
\hline Depth (m) & -24.8 & -24.8 & -23.0 & -17.8 & -14.2 & -13.8 & $-13-3$ & -10.8 & -9.8 & -8.8 & -6.8 & -5.6 & -3.8 & -9.8 & -2.6 & -1.4 & $\mathbf{0}$ \\
\hline$(w t \%)$ & & & & & & & & & & & & & & & & & \\
\hline $\mathbf{A l}_{2} \mathbf{O}_{3}$ & 0.99 & 1.16 & 1.28 & 1.13 & 0.73 & 0.85 & 1.03 & 1.12 & 1.98 & 1.32 & 1.42 & 1.01 & 1.15 & 5.21 & 14.8 & 28.1 & 10.91 \\
\hline $\mathrm{CaO}$ & 0.85 & 0.69 & 0.59 & 0.65 & 0.53 & 0.87 & 0.75 & 0.48 & 0.27 & 0.42 & 0.4 & 0.41 & 0.11 & 0.12 & 0.01 & 0.01 & $<0.01$ \\
\hline $\mathrm{Cr}_{2} \mathrm{O}_{3}$ & 0.40 & 0.51 & 0.61 & 0.38 & 0.58 & 0.46 & 0.53 & 0.65 & 0.55 & 0.82 & 0.6 & 0.54 & 0.67 & 3.16 & 2.35 & 1.67 & 0.75 \\
\hline $\mathrm{CO}_{3} \mathrm{O}_{4}$ & 0.016 & 0.015 & 0.018 & 0.015 & 0.016 & 0.015 & 0.016 & 0.023 & 0.017 & 0.019 & 0.025 & 0.02 & 0.026 & 0.183 & 0.174 & 0.189 & 0.022 \\
\hline $\mathrm{CuO}$ & 0.005 & 0.006 & 0.007 & 0.007 & 0.007 & 0.008 & 0.006 & $<0.005$ & 0.01 & 0.008 & 0.008 & $<0.005$ & 0.009 & 0.023 & 0.019 & 0.013 & 0.015 \\
\hline $\mathrm{Fe}_{2} \mathrm{O}_{3}(\mathrm{~T})$ & 8.59 & 9.96 & 11.45 & 9.08 & 10.26 & 8.63 & 9.25 & 13.51 & 12.74 & 9.92 & 12.79 & 13.41 & 12.56 & 57.84 & 57.33 & 35.84 & 58.42 \\
\hline $\mathrm{K}_{2} \mathrm{O}$ & 0.04 & 0.01 & 0.01 & $<0.01$ & 0.01 & 0.01 & 0.03 & 0.01 & 0.01 & 0.01 & $<0.01$ & $<0.01$ & 0.01 & $<0.01$ & $<0.01$ & $<0.01$ & $<0.01$ \\
\hline MgO & 43.17 & 34.96 & 31.03 & 37.41 & 38.03 & 41.73 & 35.01 & 32.41 & 31.17 & 31.77 & 28.46 & 29.80 & 31.18 & 3.23 & 0.66 & 0.41 & 0.1 \\
\hline $\mathrm{MnO}$ & 0.125 & 0.121 & 0.151 & 0.111 & 0.124 & 0.126 & 0.121 & 0.174 & 0.132 & 0.127 & 0.178 & 0.152 & 0.167 & 1.409 & 1.071 & 0.955 & 0.068 \\
\hline $\mathrm{Na}_{2} \mathrm{O}$ & 0.07 & 0.03 & 0.02 & 0.03 & 0.06 & 0.10 & 0.07 & 0.05 & 0.03 & 0.04 & 0.02 & 0.02 & 0.03 & 0.01 & $<0.01$ & $<0.01$ & $<0.01$ \\
\hline NiO & 0.325 & 1.72 & 2.742 & 1.223 & 1.092 & 0.712 & 1.464 & 1.329 & 1.53 & 1.203 & 1.900 & 1.627 & 2.108 & 1.776 & 0.514 & 0.216 & 0.131 \\
\hline $\mathbf{P}_{2} \mathbf{O}_{5}$ & $<0.01$ & $<0.01$ & 0.01 & $<0.01$ & $<0.01$ & $<0.01$ & $<0.01$ & 0.01 & $<0.01$ & $<0.01$ & 0.01 & 0.01 & 0.01 & 0.01 & 0.01 & 0.01 & 0.05 \\
\hline $\mathrm{SiO}_{2}$ & 43.21 & 42.59 & 42.98 & 42.63 & 41.06 & 43.54 & 42.95 & 41.54 & 40.83 & 42.08 & 42.91 & 42.51 & 39.26 & 16.84 & 10.06 & 15.08 & 15.49 \\
\hline $\mathrm{TiO}_{2}$ & 0.02 & 0.01 & 0.02 & 0.02 & 0.01 & 0.01 & 0.02 & 0.01 & 0.03 & 0.01 & 0.02 & 0.02 & 0.02 & 0.03 & 0.05 & 0.14 & 0.08 \\
\hline $\mathrm{V}_{2} \mathrm{O}_{5}$ & 0.010 & 0.010 & 0.009 & 0.007 & 0.009 & 0.006 & 0.009 & 0.012 & 0.009 & 0.014 & 0.012 & 0.012 & 0.01 & 0.05 & 0.043 & 0.026 & 0.026 \\
\hline LOI & 2.45 & 7.29 & 8.27 & 6.32 & 7.18 & 3.27 & 8.93 & 8.63 & 10.54 & 10.73 & 9.92 & 9.65 & 11.66 & 9.06 & 11.66 & 16.65 & 13.47 \\
\hline (ppm) & & & & & & & & & & & & & & & & & \\
\hline Sc & 9 & 11 & 13 & 8 & 9 & 10 & 9 & 13 & 13 & 13 & 17 & 13 & 14 & 68 & 67 & 40 & 43 \\
\hline Be & $<1$ & $<1$ & $<1$ & $<1$ & $<1$ & $<1$ & $<1$ & $<1$ & 2 & $<1$ & $<1$ & $<1$ & 5 & 4 & $<1$ & $<1$ & $<1$ \\
\hline $\mathbf{V}$ & 36 & 48 & 52 & 31 & 35 & 40 & 35 & 56 & 54 & 59 & 63 & 59 & 59 & 266 & 240 & 142 & 128 \\
\hline $\mathbf{C r}$ & 2850 & 3470 & 4170 & 2530 & 3850 & 3150 & 3400 & 4330 & 3550 & 5530 & 4180 & 3560 & 4510 & $>10000$ & $>10000$ & $>10000$ & 5050 \\
\hline Co & 117 & 115 & 140 & 110 & 120 & 114 & 116 & 155 & 122 & 140 & 176 & 146 & 187 & $>1000$ & $>1000$ & $>1000$ & 141 \\
\hline $\mathrm{Ni}$ & 2540 & 10000 & 10000 & 8990 & 8160 & 5430 & $>10000$ & 9350 & $>10000$ & 9260 & $>10000$ & $>10000$ & $>10000$ & $>10000$ & 4360 & 2070 & 1040 \\
\hline $\mathbf{C u}$ & $<10$ & $<10$ & $<10$ & $<10$ & 10 & 20 & $<10$ & $<10$ & 40 & 20 & 10 & 10 & 20 & 130 & 70 & 60 & 90 \\
\hline $\mathrm{Zn}$ & 50 & 60 & 70 & 120 & 420 & 60 & 70 & 220 & 770 & 60 & 170 & 80 & 1560 & 480 & 210 & 120 & 100 \\
\hline Ga & 1 & 1 & 1 & $<1$ & $<1$ & $<1$ & $<1$ & 1 & 2 & 2 & 2 & 1 & 2 & 5 & 7 & 15 & 4 \\
\hline Ge & 0.9 & 1.2 & 1.4 & 1.0 & 1.0 & 0.9 & 1.0 & 1.1 & 1.4 & 1.5 & 1.6 & 1.5 & 1.5 & 2.4 & 2.6 & 2.5 & 2.7 \\
\hline As & $<5$ & $<5$ & $<5$ & $<5$ & $<5$ & $<5$ & $<5$ & $<5$ & $<5$ & $<5$ & $<5$ & $<5$ & $<5$ & $<5$ & $<5$ & $<5$ & $<5$ \\
\hline $\mathbf{R b}$ & $<1$ & $<1$ & $<1$ & $<1$ & $<1$ & $<1$ & $<1$ & $<1$ & $<1$ & $<1$ & $<1$ & $<1$ & $<1$ & $<1$ & $<1$ & $<1$ & $<1$ \\
\hline $\mathrm{Sr}$ & 3 & $<2$ & $<2$ & $<2$ & 2 & $<2$ & 5 & 2 & 3 & 2 & 2 & $<2$ & 2 & $<2$ & $<2$ & $<2$ & $<2$ \\
\hline $\mathbf{Z r}$ & 4 & 2 & 4 & 1 & $<1$ & 1 & 3 & 1 & 5 & 1 & 1 & $<1$ & $<1$ & $<1$ & $<1$ & 73 & 14 \\
\hline $\mathrm{Nb}$ & $<0.2$ & $<0.2$ & $<0.2$ & $<0.2$ & $<0.2$ & $<0.2$ & $<0.2$ & $<0.2$ & 0.6 & $<0.2$ & $<0.2$ & $<0.2$ & $<0.2$ & $<0.2$ & 0.8 & 10.7 & 3.6 \\
\hline Mo & $<2$ & $<2$ & $<2$ & $<2$ & $<2$ & $<2$ & $<2$ & $<2$ & $<2$ & $<2$ & $<2$ & $<2$ & $<2$ & $<2$ & $<2$ & $<2$ & $<2$ \\
\hline Ag & $<0.5$ & $<0.5$ & $<0.5$ & $<0.5$ & $<0.5$ & $<0.5$ & $<0.5$ & $<0.5$ & $<0.5$ & $<0.5$ & $<0.5$ & $<0.5$ & $<0.5$ & $<0.5$ & $<0.5$ & $<0.5$ & $<0.5$ \\
\hline In & $<0.1$ & $<0.1$ & $<0.1$ & $<0.1$ & $<0.1$ & $<0.1$ & $<0.1$ & $<0.1$ & $<0.1$ & $<0.1$ & $<0.1$ & $<0.1$ & $<0.1$ & $<0.1$ & $<0.1$ & $<0.1$ & $<0.1$ \\
\hline Sn & $<1$ & $<1$ & $<1$ & $<1$ & $<1$ & $<1$ & $<1$ & $<1$ & $<1$ & $<1$ & $<1$ & $<1$ & $<1$ & $<1$ & $<1$ & $<1$ & $<1$ \\
\hline Sb & 0.4 & $<0.2$ & $<0.2$ & $<0.2$ & $<0.2$ & $<0.2$ & $<0.2$ & $<0.2$ & 0.2 & $<0.2$ & 0.3 & $<0.2$ & $<0.2$ & 0.4 & 1.0 & 0.4 & 1.8 \\
\hline Cs & 0.1 & 1.5 & 2.1 & 1.0 & 0.4 & 0.4 & 0.8 & 0.4 & 0.4 & 0.8 & 1.7 & 1.3 & 0.2 & 0.2 & $<0.1$ & 0.1 & $<0.1$ \\
\hline $\mathbf{B a}$ & 5 & 8 & 14 & 6 & 9 & 4 & 10 & 7 & 12 & 11 & 15 & 16 & 10 & 93 & 15 & 10 & 2 \\
\hline Ta & 0.01 & 0.01 & 0.01 & 0.01 & 0.01 & 0.01 & 0.01 & 0.01 & 0.09 & 0.01 & 0.01 & 0.01 & 0.01 & 0.01 & 0.06 & 1.11 & 0.32 \\
\hline $\mathbf{W}$ & 0.8 & $<0.5$ & 0.5 & 0.8 & $<0.5$ & $<0.5$ & $<0.5$ & 13.0 & 0.8 & 0.5 & $<0.5$ & $<0.5$ & $<0.5$ & $<0.5$ & 1.3 & $<0.5$ & 2.2 \\
\hline $\mathbf{P b}$ & $<5$ & $<5$ & $<5$ & $<5$ & $<5$ & $<5$ & $<5$ & $<5$ & $<5$ & $<5$ & $<5$ & $<5$ & $<5$ & $<5$ & $<5$ & $<5$ & 11 \\
\hline TI & $<0.05$ & $<0.05$ & $<0.05$ & $<0.05$ & $<0.05$ & $<0.05$ & $<0.05$ & $<0.05$ & $<0.05$ & $<0.05$ & 0.07 & $<0.05$ & $<0.05$ & 0.13 & 0.15 & 0.15 & $<0.05$ \\
\hline $\mathrm{Bi}$ & $<0.1$ & $<0.1$ & $<0.1$ & $<0.1$ & $<0.1$ & $<0.1$ & $<0.1$ & $<0.1$ & $<0.1$ & $<0.1$ & $<0.1$ & $<0.1$ & $<0.1$ & $<0.1$ & $<0.1$ & $<0.1$ & $<0.1$ \\
\hline Th & 0.08 & $<0.05$ & $<0.05$ & $<0.05$ & $<0.05$ & $<0.05$ & $<0.05$ & $<0.05$ & 0.57 & $<0.05$ & $<0.05$ & $<0.05$ & $<0.05$ & $<0.05$ & 0.45 & 6.69 & 2.81 \\
\hline $\mathbf{U}$ & 0.02 & $<0.01$ & $<0.01$ & $<0.01$ & $<0.01$ & 0.01 & $<0.01$ & 0.01 & 0.08 & 0.03 & 0.06 & $<0.01$ & 0.26 & 0.21 & 0.34 & 0.42 & 0.36 \\
\hline Hf & $<0.01$ & $<0.01$ & $<0.01$ & $<0.01$ & $<0.01$ & $<0.01$ & $<0.01$ & $<0.01$ & $<0.01$ & $<0.01$ & $<0.01$ & $<0.01$ & $<0.01$ & $<0.01$ & $<0.01$ & 2.10 & 0.40 \\
\hline Y & $<0.5$ & $<0.5$ & $<0.5$ & 0.6 & 6.8 & 0.6 & 1.9 & 1.9 & 4.8 & $<0.5$ & 29.5 & 27.9 & 29.6 & 4.8 & $<0.5$ & 0.7 & 0.8 \\
\hline La & 0.4 & 0.11 & 0.15 & 0.6 & 4.02 & 1.13 & 3.8 & 7.55 & 10.8 & 9.31 & 15 & 19.8 & 14 & 13.9 & 1.06 & 3.87 & 8.59 \\
\hline Ce & 0.57 & 0.13 & 0.18 & $<0.05$ & 0.15 & 0.2 & 0.2 & 0.07 & 3.31 & 0.53 & 0.18 & 0.06 & 5.4 & 17.5 & 5.12 & 10.1 & 16.1 \\
\hline Pr & 0.09 & 0.02 & 0.03 & 0.02 & 0.87 & 0.07 & 0.31 & 0.38 & 1.17 & 0.19 & 4.48 & 5.39 & 5.26 & 1.94 & 0.2 & 0.51 & 1.06 \\
\hline Nd & 0.26 & 0.13 & 0.11 & 0.15 & 3.18 & 0.26 & 1.05 & 1.1 & 4.23 & 0.53 & 18.2 & 21.8 & 20.8 & 6.75 & 0.69 & 1.81 & 3.27 \\
\hline Sm & 0.04 & $<0.01$ & $<0.01$ & $<0.01$ & 0.48 & $<0.01$ & 0.07 & 0.02 & 0.62 & $<0.01$ & 4.84 & 4.66 & 6.84 & 1.10 & 0.12 & 0.24 & 0.44 \\
\hline Eu & 0.020 & $<0.005$ & 0.005 & $<0.005$ & 0.142 & 0.016 & 0.023 & 0.020 & 0.169 & 0.005 & 1.450 & 1.250 & 1.870 & 0.329 & 0.038 & 0.054 & 0.086 \\
\hline Gd & 0.04 & 0.01 & 0.01 & $<0.01$ & 0.85 & 0.05 & 0.08 & 0.09 & 0.62 & $<0.01$ & 5.23 & 4.52 & 6.38 & 0.9 & 0.06 & 0.19 & 0.23 \\
\hline Tb & 0.01 & $<0.01$ & $<0.01$ & $<0.01$ & 0.11 & $<0.01$ & 0.01 & 0.01 & 0.09 & $<0.01$ & 0.88 & 0.62 & 1.19 & 0.14 & 0.02 & 0.03 & 0.04 \\
\hline Dy & 0.07 & 0.04 & 0.03 & 0.03 & 0.62 & 0.05 & 0.07 & 0.07 & 0.56 & 0.02 & 5.27 & 3.61 & 7.3 & 0.97 & 0.1 & 0.18 & 0.22 \\
\hline Нo & 0.01 & 0.01 & $<0.01$ & $<0.01$ & 0.15 & $<0.01$ & 0.02 & 0.02 & 0.12 & $<0.01$ & 1.03 & 0.76 & 1.32 & 0.18 & 0.02 & 0.03 & 0.04 \\
\hline Er & 0.04 & 0.04 & 0.03 & 0.04 & 0.49 & 0.04 & 0.07 & 0.07 & 0.39 & 0.02 & 2.81 & 2.06 & 3.96 & 0.56 & 0.07 & 0.1 & 0.12 \\
\hline Tm & 0.006 & 0.005 & 0.007 & 0.008 & 0.067 & $<0.005$ & 0.012 & 0.014 & 0.056 & $<0.005$ & 0.363 & 0.277 & 0.67 & 0.098 & 0.011 & 0.019 & 0.018 \\
\hline Yb & 0.04 & 0.03 & 0.06 & 0.06 & 0.43 & 0.05 & 0.08 & 0.11 & 0.39 & 0.02 & 2.37 & 1.62 & 4.97 & 0.74 & 0.06 & 0.14 & 0.11 \\
\hline Lu & $<0.002$ & 0.003 & 0.011 & 0.009 & 0.068 & 0.007 & 0.012 & 0.022 & 0.063 & 0.003 & 0.377 & 0.233 & 0.724 & 0.114 & 0.008 & 0.020 & 0.014 \\
\hline Total wt $\%$ & 100.30 & 99.10 & 99.19 & 99.01 & 99.71 & 100.30 & 100.20 & 99.97 & 99.84 & 98.50 & 98.68 & 99.19 & 98.98 & 98.95 & 98.75 & 99.30 & 99.52 \\
\hline ¿REE (ppm) & 1.598 & 0.553 & 0.653 & 1.012 & 11.627 & 1.908 & 5.807 & 9.546 & 22.588 & 10.673 & 62.48 & 66.66 & 80.684 & 45.221 & 7.577 & 17.293 & 30.338 \\
\hline
\end{tabular}


The same samples were analyzed using X-Ray powder diffraction (XRPD). Diffractograms were obtained at Centres Científics i Tecnològics of the Universitat de Barcelona (CGiT-UB) in a PANalytical X'Pert PRO MPD Alphal powder diffractometer in Bragg-Brentano $\theta / 2 \theta$ geometry of $240 \mathrm{~mm}$ of radius, nickel filtered $\mathrm{Cu} \mathrm{Kal}$ radiation $(\lambda=1.5406 \AA), 45 \mathrm{kV}$ and $40 \mathrm{~mA}$. The samples were scanned from 4 to $100^{\circ}(2 \theta)$ with a step size of $0.017^{\circ}$ and measuring time of 50 s per step, using an X'Gelerator detector (active length $\left.=2.122^{\circ}\right)$. Mineral-identification was facilitated by X'Pert High Score search-match software using the powder diffraction database of the International Centre for Diffraction Data (ICDD). Mineral semi-quantitative analyses were performed by the full profile fitting method (Rietveld method) using the TOPAS V4 software and the American Mineralogist Crystal Structure Database.
Minerals and textures were examined on polished thin sections under optical microscope $(\mathrm{OM})$ with both transmitted and reflected light, and under a scanning electron microscope (SEM) Quanta 200 FEI, XTE 325/D8395, with an INCA Energy Dispersive Spectrometer (EDS) microanalysis system at the CCiT-UB.

Electron microprobe analyses (EMPA) of representative samples were performed with a JEOL JXA-8230 electron microprobe, equipped with five wavelength-dispersive spectrometers and an energy-dispersive spectrometer. The operating conditions were $20 \mathrm{kV}$ accelerating voltage, $15 \mathrm{nA}$ beam current, $2 \mu \mathrm{m}$ beam diameter and counting time of $20 \mathrm{~s}$ per element. The calibration standards used were wollastonite $(\mathrm{Si}, \mathrm{Ca})$, corundum $(\mathrm{Al})$, orthoclase $(\mathrm{K})$, hematite $(\mathrm{Fe})$, periclase $(\mathrm{Mg})$, rhodonite $(\mathrm{Mn}), \mathrm{NiO}(\mathrm{Ni})$, metallic $\mathrm{Co}(\mathrm{Co})$, rutile $(\mathrm{Ti})$, albite $(\mathrm{Na}), \mathrm{Cr}_{2} \mathrm{O}_{3}(\mathrm{Cr}), \mathrm{V}(\mathrm{V})$, and $\mathrm{Sc}(\mathrm{Sc})$.

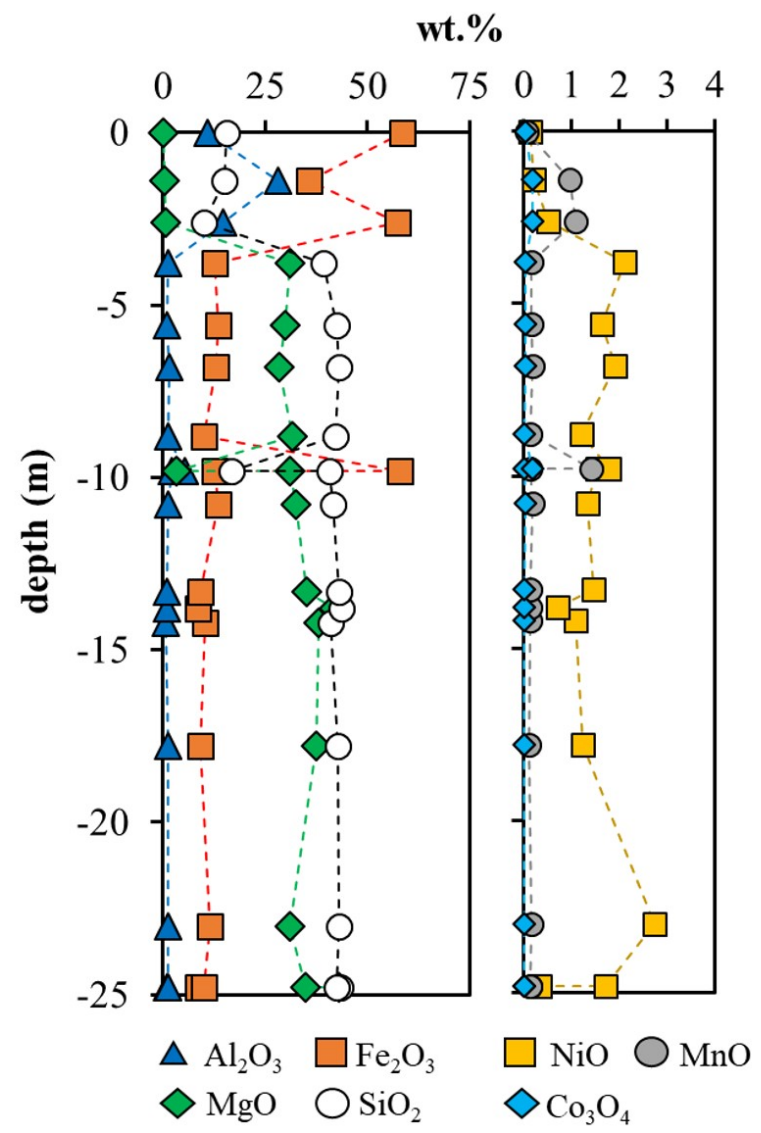

ppm

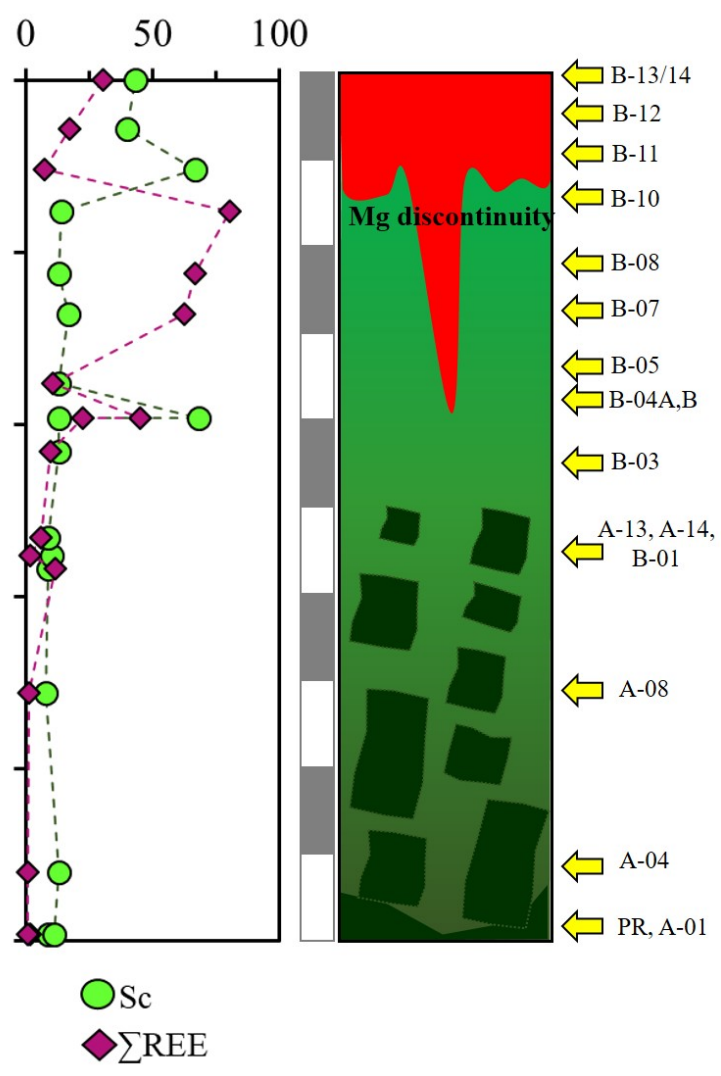

Figure 4 Idealized Ni-laterite profile (right) from the Loma de Hierro laterite deposit (Venezuela) showing the location of the samples, with contents of major and relevant minor elements (in wt.\% oxide), Sc and REE (in ppm). 
Structural formulae were calculated on the basis of 1.5 oxygens (goethite), 4 oxygens (olivine, magnetite, Cr-spinel), 6 oxygens (pyroxene), 7 oxygens (serpentine), and 11 oxygens (garnierite). Structural formulae of primary serpentine (Srp-I) were calculated taking into account all $\mathrm{Fe}$ as $\mathrm{Fe}(\mathrm{II})$, while those of secondary serpentine (Srp-II) and garnierite were obtained taking into account all $\mathrm{Fe}$ as Fe(III), based on XANES data on Srp-I, Srp-II and garnierites from the Dominican Republic (Roqué-Rosell et al., 2017). In addition, the molar
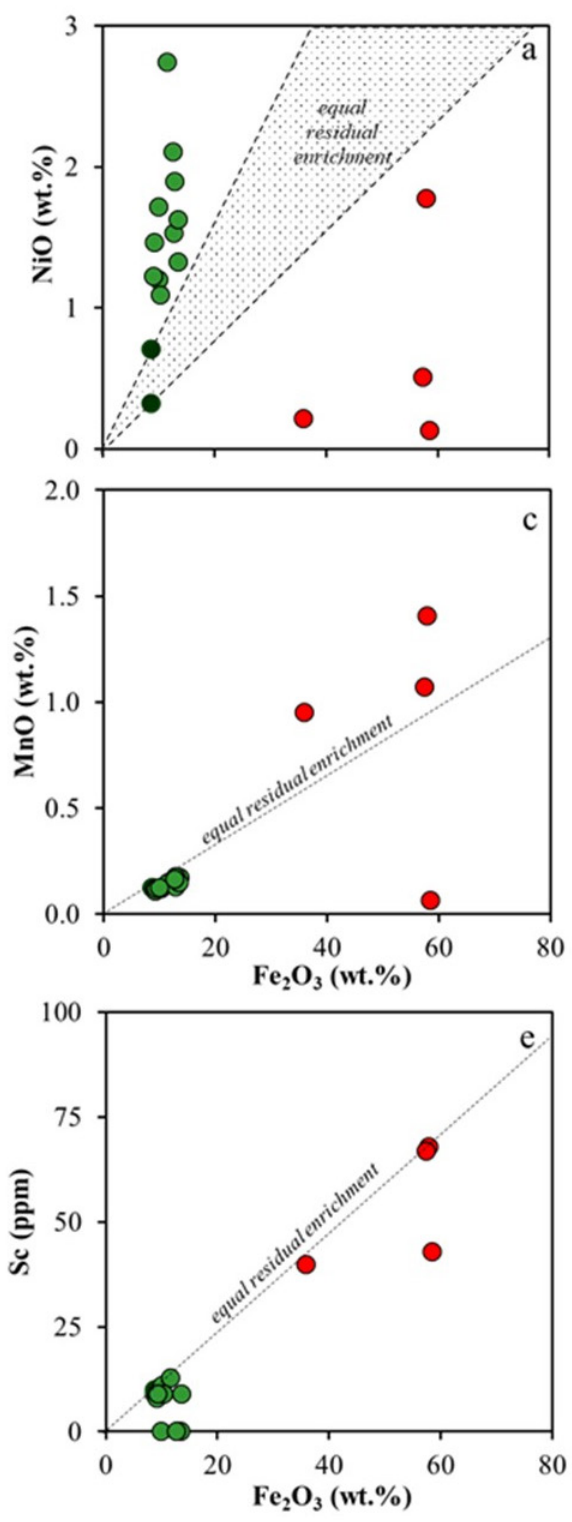

percentage of the talc-like phase (kerolite-pimelite) in the garnierite mixture was calculated using the equation proposed by Soler et al. (2008).

\section{Whole rock chemistry}

The concentrations of major and minor elements (in wt. \%) in selected samples from Loma de Hierro are given in Table 1. Figure 4 shows the general trend observed across the Loma de Hierro profile
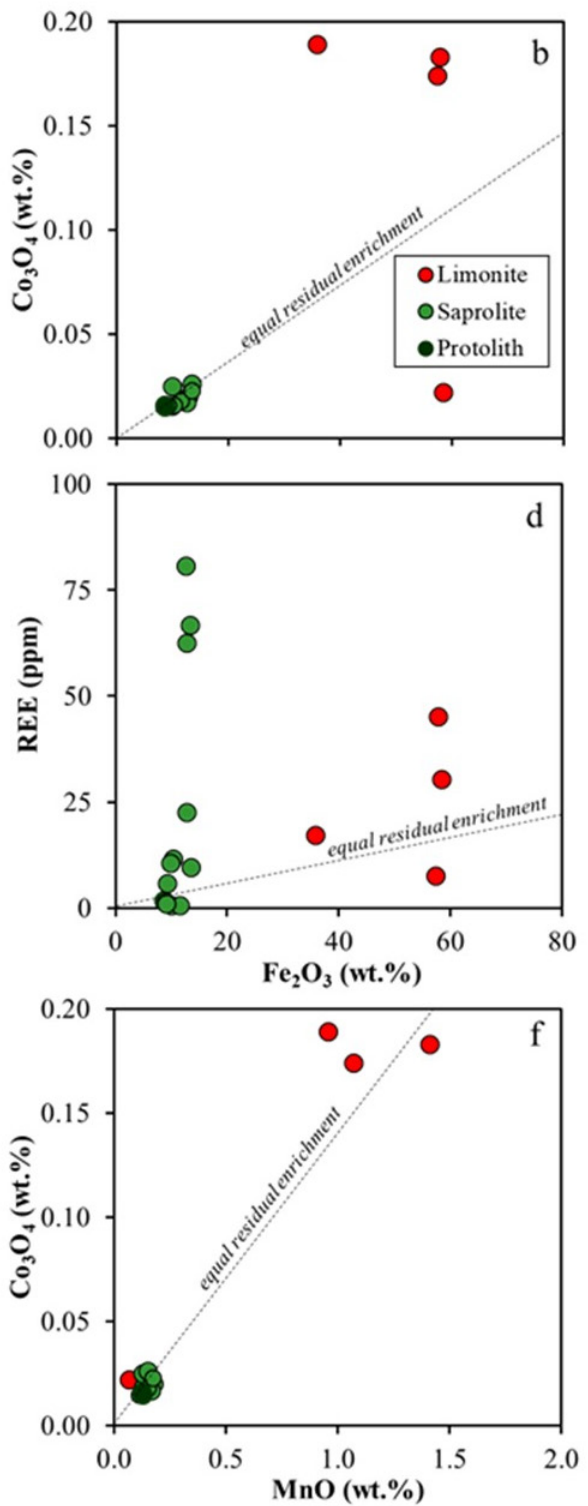

Figure 5 Content of (a) $\mathrm{NiO}$ (in wt.\%), (b) $\mathrm{Co}_{3} \mathrm{O}_{4}$ (in wt.\%), (c) MnO (in wt.\%), (d) $\Sigma \mathrm{REE}$ (in ppm), and (e) $\mathrm{Sc}$ (in ppm) versus Fe $\mathrm{O}_{3}$ content (in wt.\%), and (f) $\mathrm{Co}_{3} \mathrm{O}_{4}$ (in wt.\%) versus $\mathrm{MnO}$ content (in wt.\%) of the samples of the Loma de Hierro Ni-laterite deposit. Dashed lines and shadowed area show the equal residual enrichment trend. 
concerning the distribution of the major elements $(\mathrm{Si}, \mathrm{Mg}, \mathrm{Fe}$, and $\mathrm{Al})$, relevant minor elements $(\mathrm{Ni}$, $\mathrm{Co}$, and $\mathrm{Mn}$ ), Sc, and Rare earth elements (REE). $\mathrm{Si}$ and $\mathrm{Mg}$ are the main components of the protolith samples, with values around $43 \mathrm{wt} . \%$ for both $\mathrm{SiO}_{2}$ and $\mathrm{MgO}$. The saprolite zone presents a quite similar content of $\mathrm{Si}\left(\sim 42 \mathrm{wt} . \% \mathrm{SiO}_{2}\right)$, and $\mathrm{Mg}$ contents in the range of $28-38$ wt. $\% \mathrm{MgO}$. The limonite zone is characterized by significantly lower $\mathrm{Si}$ contents $\left(10-16\right.$ wt. $\left.\% \mathrm{SiO}_{2}\right)$, and extremely low $\mathrm{Mg}$ concentrations (<3 wt. $\% \mathrm{MgO}$ ), clearly defining the $\mathrm{Mg}$ discontinuity (Figure 4). In the limonite zone, $\mathrm{Fe}$ and $\mathrm{Al}$ are the main components, with concentrations of $38-58$ wt. $\% \mathrm{Fe}_{2} \mathrm{O}_{3}$ and 5-28 wt. $\% \mathrm{Al}_{2} \mathrm{O}_{3}$.

$\mathrm{Ni}$ is enriched in the saprolite zone $(1.1-2.7$ wt. $\% \mathrm{NiO})$ compared to the protolith $(<0.7 \mathrm{wt} . \%$ $\mathrm{NiO}$; Figure 5a). In the limonite zone, $\mathrm{Mn}$ and $\mathrm{Co}$ concentrations are close to one order of magnitude higher than in the saprolite zone and in the protolith, achieving values up to $1.40 \mathrm{wt} . \% \mathrm{MnO}$ and 0.19 wt. $\% \mathrm{Co}_{3} \mathrm{O}_{4}$ (Figures 5b, 5c and 5f).

The total REE concentration in the protolith samples and the lower part of the saprolite horizon is low, below 6 ppm. However, it increases up to $81 \mathrm{ppm}$ in the upper part of the saprolite mainly due to the contribution of $\mathrm{Y}, \mathrm{La}$ and $\mathrm{Nd}$. In the limonite zone, total REE concentration decreases to values below $45 \mathrm{ppm}$, being $\mathrm{Ce}$, La, and $\mathrm{Nd}$ the most relevant REE (Figure 5d).

REE chondrite-normalized patterns of protolith and saprolite samples (Figure 6) are quite similar, despite the Ce negative anomalies in saprolite samples, also observed in other deposits (Aiglsperger et al., 2016, Ulrich et al., 2019). REE patterns from the limonite zone have a negative continuous slope from $\mathrm{La}$ to $\mathrm{Lu}$, with slightly positive $\mathrm{Ce}$ anomalies. Sc contents are clearly higher in the limonite zone (Figure 5e), where they range from 43 to $58 \mathrm{ppm}$, whereas in the saprolite and protolith samples values range from 8 to $17 \mathrm{ppm}$ (Figure 4).

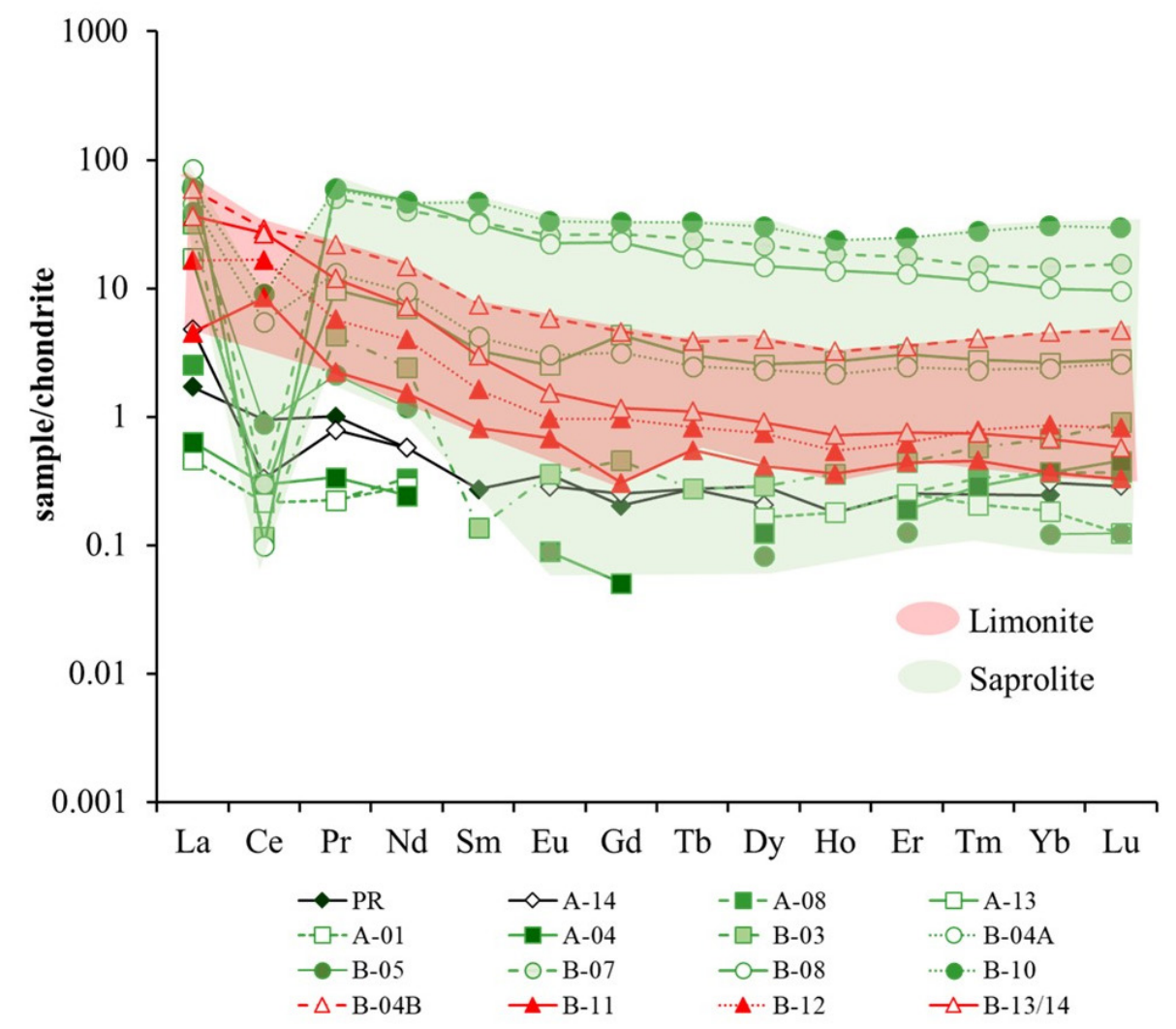

Figure 6 Chondrite normalized rare earth element (REE) patterns from Loma de Hierro Ni laterite deposit. Normalization values are from Anders and Grevesse (1989). 


\section{Mineralogy and textures}

Semi-quantitative analyses shown in Figure 7 give a clear picture of the mineral evolution from the bedrock towards the top of the profile.

The protolith consists of a slightly serpentinized harzburgite. According to XRPD, harzburgite is made up by olivine (65-70 wt.\%) and orthopyroxene (10-15 wt.\%), with minor amounts of lizardite, chrysotile, and kerolite (10-15 wt.\%), chlorite (1 wt. \%) and amphibole (in one of the samples, 4 wt.\%; Figure 7). The lowest part of the saprolite zone (represented by samples A-01, A-04, A-08, A-13, and B-03) is characterized by still having a significant amount of olivine (13-46 wt.\%) and orthopyroxene (up to $15 \mathrm{wt} . \%$; Figure 7), but the main component are phyllosilicate minerals (up to $68 \%$ wt. $\%$; Figure 7 ). Lizardite and chrysotile contents range from 16 to 35 and 2 to 7 wt. $\%$, respectively while kerolite content in sample A-04 is close to $36 \mathrm{wt} . \%$ and above $19 \mathrm{wt} . \%$ in the other samples. This zone is also characterized by the presence of minor amounts of garnierites (Soler et al., 2008), described as a group of Ni-enriched secondary phyllosilicates (including serpentine, the "talc-like" kerolite-pimelite series, sepiolite, chlorite, and/or smectite) often occurring as fine grained, poorly crystalline, intimate mixtures (e.g., Brindley, 1978). Towards the surface, the upper saprolite, represented by samples B-04-A, B-05, $\mathrm{B}-07, \mathrm{~B}-08$, and $\mathrm{B}-10$, is poorer in olivine $(0-6$ wt. $\%$ ) and orthopyroxene ( $<15 \mathrm{wt} . \%)$, and richer in lizardite (27-35 wt.\%) than the lower saprolite horizon (Figure 7). Kerolite and chrysotile contents are around 37 and 7 wt. $\%$, respectively. Up to 16 wt. $\%$ of chlorite is observed within the upper saprolite horizon. Finally, the limonite zone, at the top of the profile, is characterized by a sharp increase in goethite (40-57 wt.\%), hematite (9-16 wt.\%), and gibbsite (4-35 wt.\%). Quartz content ranges from 2 to 17 wt.\% (Figure 7).

Concerning textures, under OM and SEM olivine in protolith displays undulate extinction, and orthopyroxene has kink bands, indicating plastic deformation at high temperatures. In addition, orthopyroxene may contain clinopyroxene exsolutions. The serpentine minerals result from the alteration of the protolith before the laterization process and therefore are named Srp-I. They appear surrounding the olivine and pyroxene grains, and in fractures crosscutting them and defining some subgrains (Figures 8a and 8b).

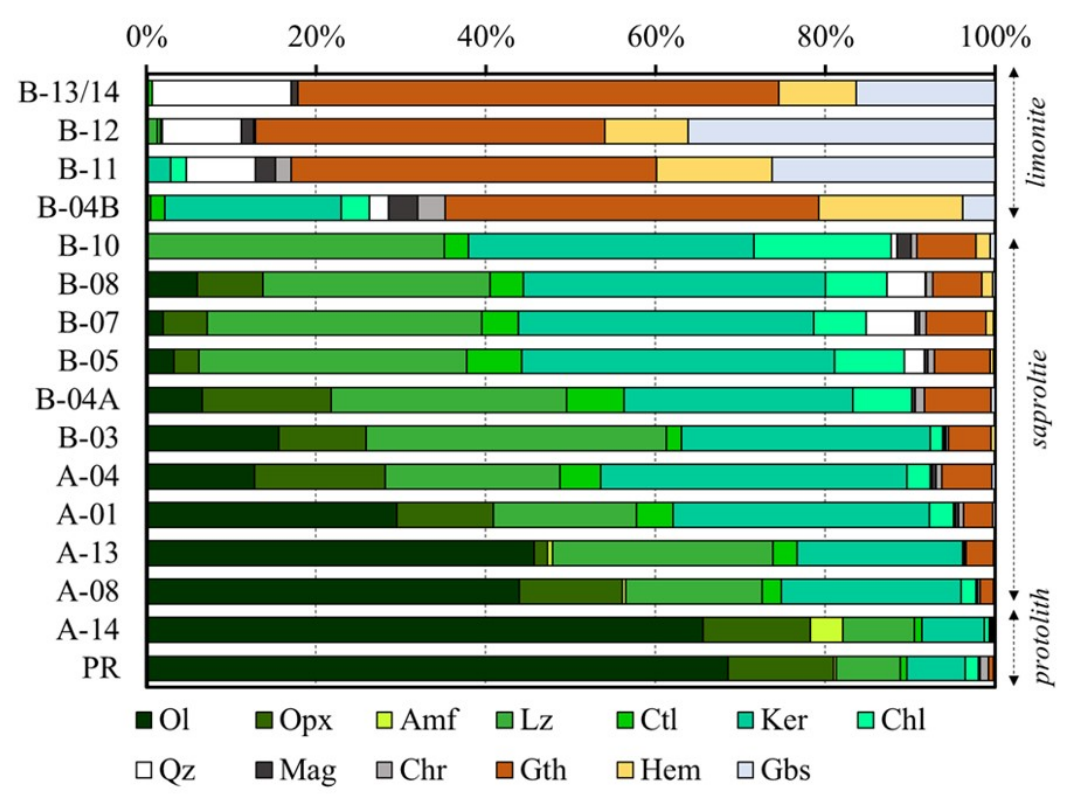

Figure 7 Semi-quantitative representation of X-Ray powder diffraction (XRPD) results (in wt.\%), obtained with Rietveld method. OI (olivine); Opx (orthopyroxene); Amf (amphibole); Lz (lizardite); Ctl (chrysotile); Ker (kerolite); Chl (chlorite); Qz (quartz); Mag (magnetite); Chr (Cr-spinel); Gth (goethite); Hem (hematite); Gbs (gibbsite). 


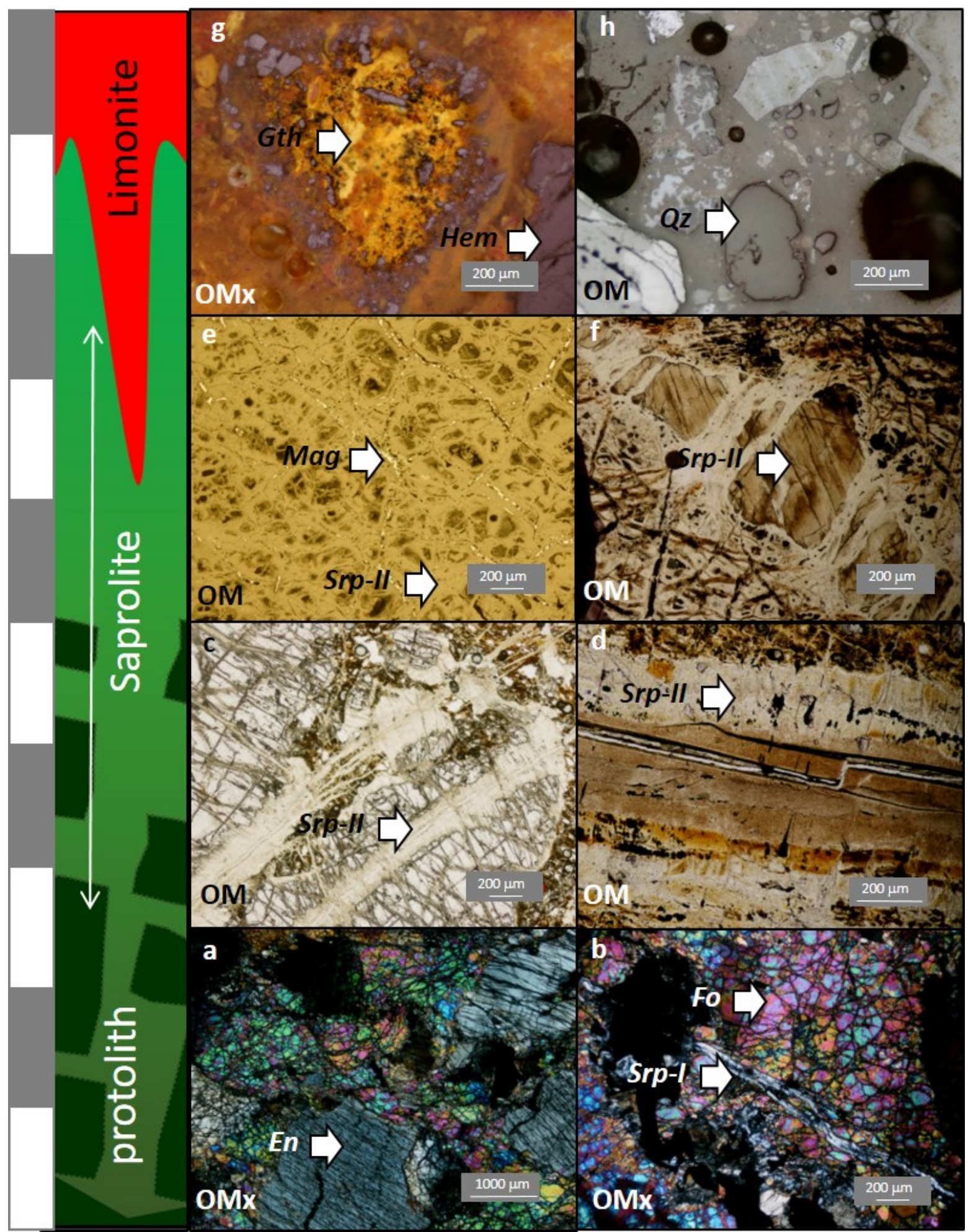

Figure 8 Plane polarized light (OM) and crossed polars (OMx) optical micrographs of (a-b) the protolith, (c-f) the saprolite horizon and $(\mathbf{g}-\mathbf{h})$ the limonite horizon. (a-b) Transmitted light optical images of sample A-14, showing well defined grains of enstatite (En) and fractured forsterite (Fo) crossed by primary serpentine (Srp-l). (c-d) Transmitted light optical images of sample A-1, showing the formation of Srp-II in fractures crossing protolith forming minerals. (e-f) Transmitted light optical images of sample B-10, showing previous forsterite and enstatite grains replaced by serpentine and surrounded by magnetite. (g-h) Reflected light optical images of sample B-13/14, showing grains of goethite, hematite, and quartz. 
The lower saprolite has a higher degree of alteration of olivine, with serpentine minerals in fractures and subgrain rims, and pseudomorphically replacing orthopyroxene grains (Figures 8c, 8d, and 9c). However, olivine and orthopyroxene contents are still significant; the original fabric is mostly preserved and porosity has increased due to the dissolution of olivine subgrains. Most of the serpentine minerals observed in this horizon were formed during the laterization process and called Srp-II to discern them from Srp-I, of oceanic origin. Garnierites appear as fracture fillings (Figure 9d).

By contrast, the upper part of the saprolite is brown, clumpy, and significantly more altered than the lower saprolite. Srp-II practically replaces pseudomorphically all orthopyroxene and olivine grains (Figures 8e and 8f), but the original texture of the rock has collapsed and porosity is reduced. Limonite-horizon samples are brown to reddish, formed by disaggregated material (suggesting possible removal or transport along a few meters), and with a complete loss of the original texture (Figures 8g, 8h and 9h). According to OM and SEM observations, magnetite (Mag) and Cr-spinel (Chr) are identified as accessory minerals in the lower saprolite zone (Figure 9a and 9b) and the upper saprolite zone (Figure 9e). In the latter, Fe- and Mn-oxy-hydroxides and chlorite are also observed (Figure 9f). In the limonite zone, relict Cr-spinel partially altered to ferrian chromite, magnetite partially altered to goethite or hematite, quartz, altered phyllosilicates, Mn-oxy-hydroxides (Figures $9 \mathrm{~g}$ and $9 \mathrm{~h}$ ), and minor amounts of rutile and ilmenite have also been observed.

\section{Mineral chemistry of the Ni-bearing phases}

In Tables 2-4, representative EMPA analyses and structural formulae of the main minerals occurring in the studied profile are given. In the protolith, olivine has a forsteritic composition with an average composition of $\mathrm{Fo}_{90}$ (Table 2). It is the main carrier of $\mathrm{Ni}$, with 0.4 wt. $\% \mathrm{NiO}$ (compare with 0.33 wt. $\%$ NiO of the whole rock, Table 1). Since forsterite represents about $70 \mathrm{wt} . \%$ of the protolith (see Figure 7), it can be concluded that around 90 wt. $\%$ of the bulk $\mathrm{Ni}$ in the protolith is contained in olivine. Orthopyroxene corresponds to an enstatite with an average composition of $\mathrm{En}_{92}$ characterized by a $\mathrm{Mg} \#$ " $[\mathrm{Mg} \#=\mathrm{Mg} /(\mathrm{Mg}+\mathrm{Fe})]$ " ranging from 0.91 to 0.92 . The $\mathrm{Al}_{2} \mathrm{O}_{3}$ content of enstatite ranges from 0.44 to 3.03 wt. $\%$, while that of $\mathrm{CaO}$ varies from 0.20 to 3.38 wt. $\%$. Cr and $\mathrm{Ni}$ contents are below 0.9 wt. $\% \mathrm{Cr}_{2} \mathrm{O}_{3}$ and 0.2 wt. $\% \mathrm{NiO}$ (Table 2). The content of $\mathrm{Ni}$ in Srp-I is not higher than 0.4 wt. $\% \mathrm{NiO}(<0.02$ atoms per formula unit [apfu] Ni), while Fe ranges from 2.85 to 5.42 wt.\% $\mathrm{FeO}$ (0.11-0.22 apfu Fe; Table 3, Figure 10). Its average structural formula is $\left(\mathrm{Mg}_{2.8} \mathrm{Fe}_{0.1} \mathrm{Ni}_{0.01} \mathrm{Al}_{0.02}\right)$ $\left.\mathrm{Si}_{2.0} \mathrm{O}_{5}(\mathrm{OH})_{4}\right)$. Cr-spinel is rich in $\mathrm{Al}(\mathrm{Cr} \#=0.48$ to 0.52 ;" $\mathrm{Cr} \#=\mathrm{Cr} /(\mathrm{Cr}+\mathrm{Al}$ " $))$; and $\mathrm{Mg}(\mathrm{Mg} \#=$ 0.48 to 0.52 ), and $\mathrm{TiO}_{2}$ and $\mathrm{NiO}$ contents are 0.05 wt. $\%$ and 0.07 wt. $\%$ respectively, while $\mathrm{MnO}$ is between 0.27 and 0.31 wt.\% (Table 2). In magnetite $\mathrm{NiO}$ content is less than 0.08 wt. $\%$ (Table 2).

Srp-II contains $1.4-4.1$ wt. $\% \mathrm{NiO}(0.06-0.16$ apfu $\mathrm{Ni}$ ) and 3.0-6.2 wt. $\% \mathrm{Fe}_{2} \mathrm{O}_{3}(0.11-0.23$ apfu $\mathrm{Fe}$ ), with an average structural formula of $\left(\mathrm{Mg}_{2.42} \mathrm{Fe}_{0.16} \mathrm{Ni}_{0.11} \mathrm{Al}_{0.08}\right)_{\mathrm{Si}_{2.06}} \mathrm{O}_{5}(\mathrm{OH})_{4}$. Figure 10 shows the relationship among the octahedral elements in Srp-I and Srp-II of Loma de Hierro, compared to compositions of Srp-I and II from the literature (Golightly and Arancibia 1979; Tauler et al., 2017; Villanova-de-Benavent et al., 2017). There is a clear negative correlation between $\mathrm{Mg}$ and $\mathrm{Ni}$ (Figure 10a), as well as between Fe and $\mathrm{Mg}$ (Figure 10c), or Fe+Ni and Mg (Figure 10d), suggesting that $\mathrm{Ni}$ and $\mathrm{Fe}$ exchanges with $\mathrm{Mg}$ in the octahedral site of serpentine. Ni and Fe correlation indicates that Ni content in Srp-II increases more rapidly than that of $\mathrm{Fe}$. Those results agree with other serpentine mineral compositions reported in the literature.

Their structural formulae usually give a significant deficiency in octahedral cations (Table 3), which has also been observed in Srp-II from Indonesia (Golightly and Arancibia, 1979) and in 


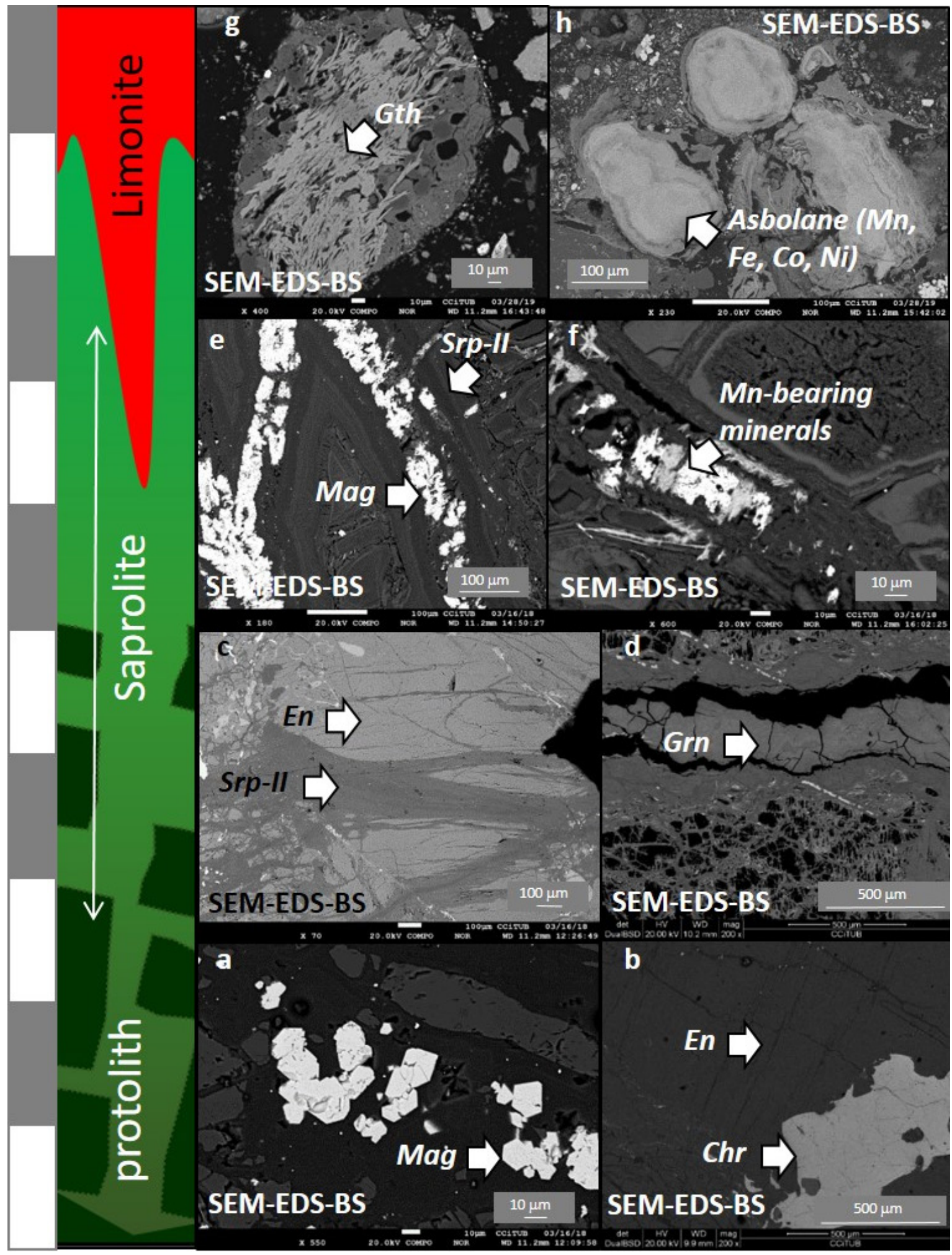

Figure 9 Backscattered electron microscope (SEM-EDS-BS) images of (a-b) the protolith, (c-f) the saprolite horizon and (g-h) the limonite horizon. (a-b) SEM-EDS-BS images of sample A-14, showing grains of magnetite (Mag) and Cr-spinel (Chr). (c-d) SEM-EDS-BS images of sample A-1, showing the formation of Srp-II and garnierites (Grn) in fractures crossing protolith forming minerals. (e-f) SEM-EDS-BS images of sample B-10, showing the relationship between magnetite, Srp-II, and Mn-oxy-hydroxides. (g) SEM-EDS-BS image of goethite (Gth) in sample B-13. (h) SEM-EDS-BS image of Mn-oxy-hydroxides with $\mathrm{Co}$, Ni, and Fe in sample B-11. 
Table 2. Representative electron microprobe analyses (in wt.\%) and structural formulae (in atoms per formula unit, apfu) of forsterite, enstatite, magnetite and $\mathrm{Cr}$-spinel of Loma de Hierro samples.

\begin{tabular}{|c|c|c|c|c|c|c|c|c|c|c|c|c|c|c|c|}
\hline & \multicolumn{3}{|c|}{ Forsterite } & \multicolumn{4}{|c|}{ Enstatite } & \multicolumn{4}{|c|}{ Magnetite } & \multicolumn{4}{|c|}{ Chromium Spinel } \\
\hline Anal.No. & 1 & 2 & 3 & 1 & 2 & 3 & 4 & 1 & 2 & 3 & 4 & 1 & 2 & 3 & 4 \\
\hline $\mathrm{SiO}_{2}$ & 40.81 & 40.83 & 41.07 & 56.53 & 55.85 & 54.95 & 55.31 & 0.88 & 0.68 & 0.26 & 0.31 & 0.03 & 0.03 & 0.04 & 0.16 \\
\hline $\mathrm{Al}_{2} \mathrm{O}_{3}$ & 0.00 & 0.01 & 0.01 & 1.23 & 2.37 & 2.72 & 2.74 & 0.00 & 0.00 & 0.00 & 0.00 & 25.24 & 26.14 & 27.64 & 26.37 \\
\hline $\mathrm{K}_{2} \mathrm{O}$ & 0.01 & 0.00 & 0.03 & 0.04 & 0.00 & 0.00 & 0.02 & 0.00 & 0.01 & 0.03 & 0.00 & 0.01 & 0.02 & 0.01 & 0.03 \\
\hline $\mathrm{CaO}$ & 0.00 & 0.03 & 0.05 & 1.48 & 2.39 & 1.67 & 3.38 & 0.00 & 0.04 & 0.04 & 0.00 & 0.02 & 0.00 & 0.01 & 0.02 \\
\hline $\mathrm{TiO}_{2}$ & 0.00 & 0.00 & 0.00 & 0.03 & 0.02 & 0.00 & 0.04 & 0.11 & 0.01 & 0.00 & 0.01 & 0.05 & 0.06 & 0.05 & 0.05 \\
\hline $\mathrm{Cr}_{2} \mathrm{O}_{3}$ & 0.00 & 0.00 & 0.03 & 0.03 & 0.73 & 0.74 & 0.92 & 0.76 & 0.24 & 0.00 & 0.00 & 41.58 & 39.32 & 38.28 & 38.86 \\
\hline $\mathrm{Na}_{2} \mathrm{O}$ & 0.04 & 0.03 & 0.00 & 0.30 & 0.00 & 0.01 & 0.03 & 0.06 & 0.01 & 0.03 & 0.04 & 0.03 & 0.06 & 0.08 & 0.00 \\
\hline $\mathrm{NiO}$ & 0.37 & 0.43 & 0.43 & 0.10 & 0.11 & 0.09 & 0.10 & 0.08 & 0.00 & 0.04 & 0.06 & 0.07 & 0.06 & 0.06 & 0.05 \\
\hline $\mathrm{CoO}$ & 0.03 & 0.01 & 0.03 & 0.00 & 0.00 & 0.00 & 0.01 & 0.10 & 0.12 & 0.10 & 0.11 & 0.09 & 0.10 & 0.09 & 0.12 \\
\hline $\mathrm{FeO}$ & 8.88 & 8.47 & 8.80 & 5.53 & 5.47 & 5.41 & 5.16 & 91.05 & 91.44 & 88.85 & 89.33 & 19.09 & 20.27 & 20.13 & 20.62 \\
\hline $\mathrm{MnO}$ & 0.11 & 0.12 & 0.12 & 0.16 & 0.12 & 0.14 & 0.12 & 0.03 & 0.00 & 0.10 & 0.09 & 0.27 & 0.31 & 0.31 & 0.31 \\
\hline $\mathrm{V}_{2} \mathrm{O}_{3}$ & 0.04 & 0.01 & 0.00 & 0.00 & 0.00 & 0.02 & 0.01 & 0.02 & 0.01 & 0.01 & 0.02 & 0.16 & 0.27 & 0.24 & 0.18 \\
\hline Total & 100.41 & 100.71 & 100.86 & 99.53 & 100.60 & 99.19 & 100.13 & 93.35 & 93.12 & 89.68 & 90.31 & 98.30 & 98.01 & 98.51 & 97.47 \\
\hline O (str.form) & 4 & 4 & 4 & 6 & 6 & 6 & 6 & 4 & 4 & 4 & 4 & 4 & 4 & 4 & 4 \\
\hline Si & 0.994 & 0.990 & 0.995 & 1.962 & 1.925 & 1.917 & 1.919 & 0.033 & 0.026 & 0.011 & 0.012 & 0.001 & 0.001 & 0.001 & 0.005 \\
\hline Al & 0.000 & 0.000 & 0.000 & 0.051 & 0.096 & 0.112 & 0.112 & 0.000 & 0.000 & 0.000 & 0.000 & 0.929 & 0.965 & 1.008 & 0.979 \\
\hline $\mathbf{K}$ & 0.000 & 0.000 & 0.001 & 0.002 & 0.000 & 0.000 & 0.001 & 0.000 & 0.001 & 0.001 & 0.000 & 0.000 & 0.001 & 0.000 & 0.001 \\
\hline Ca & 0.000 & 0.001 & 0.001 & 0.055 & 0.088 & 0.062 & 0.126 & 0.000 & 0.002 & 0.002 & 0.000 & 0.001 & 0.000 & 0.000 & 0.001 \\
\hline $\mathbf{T i}$ & 0.000 & 0.000 & 0.000 & 0.001 & 0.001 & 0.000 & 0.001 & 0.003 & 0.000 & 0.000 & 0.000 & 0.001 & 0.001 & 0.001 & 0.001 \\
\hline $\mathrm{Cr}$ & 0.000 & 0.000 & 0.001 & 0.001 & 0.020 & 0.020 & 0.025 & 0.023 & 0.007 & 0.000 & 0.000 & 1.027 & 0.974 & 0.937 & 0.968 \\
\hline Mg & 1.819 & 1.835 & 1.816 & 1.764 & 1.722 & 1.739 & 1.670 & 0.016 & 0.032 & 0.013 & 0.020 & 0.543 & 0.531 & 0.534 & 0.503 \\
\hline $\mathbf{N a}$ & 0.002 & 0.001 & 0.000 & 0.020 & 0.000 & 0.001 & 0.002 & 0.004 & 0.001 & 0.002 & 0.003 & 0.002 & 0.004 & 0.005 & 0.000 \\
\hline $\mathbf{N i}$ & 0.007 & 0.008 & 0.008 & 0.003 & 0.003 & 0.002 & 0.003 & 0.002 & 0.000 & 0.001 & 0.002 & 0.002 & 0.001 & 0.002 & 0.001 \\
\hline Co & 0.001 & 0.000 & 0.001 & 0.000 & 0.000 & 0.000 & 0.000 & 0.003 & 0.004 & 0.003 & 0.003 & 0.002 & 0.002 & 0.002 & 0.003 \\
\hline $\mathrm{Fe}$ & 0.181 & 0.172 & 0.178 & 0.161 & 0.158 & 0.158 & 0.150 & & & & & 0.499 & 0.531 & 0.521 & 0.543 \\
\hline $\mathrm{Fe}(\mathrm{II})$ & & & & & & & & 0.967 & 0.975 & 0.988 & 0.986 & & & & \\
\hline $\mathrm{Fe}$ (III) & & & & & & & & 1.934 & 1.949 & 1.977 & 1.972 & & & & \\
\hline Mn & 0.002 & 0.002 & 0.003 & 0.005 & 0.003 & 0.004 & 0.004 & 0.001 & 0.000 & 0.003 & 0.003 & 0.007 & 0.008 & 0.008 & 0.008 \\
\hline
\end{tabular}

the Falcondo mining district (Tauler et al., 2017). This deficiency is more important with higher $\mathrm{Ni}$ and Fe contents.

Compositional analyses shown in Table 3 suggest that garnierites from Loma de Hierro are mixtures between serpentine and a talc-like phase (kerolite-pimelite), with a $\mathrm{Ni}$ content ranging from 19 to 22 wt. $\% \mathrm{NiO}(1.24-1.53 \mathrm{Ni}$ apfu, calculated on the basis of 11 oxygens), and they are Fe and $\mathrm{Al}$ poor ( $\mathrm{Al}$ is below detection limit). As displayed in Figure 11, these mixtures are kerolite-pimelite dominated (talc percentage ranging from 71 to 75 wt. \%). They have similar compositions to the composition of Loma de Hierro garnierite of Soler et al. (2008; 63 wt. \% talc), to those reported in the Falcondo mining district, Dominican Republic (Villanova-de-Benavent et al., 2014; Tauler et al., 2017), and to those described by Wells et al. (2009) and Cathelineau et al. (2016) in New Caledonia
(Figure 11). Furthermore, garnierites from Loma de Hierro follow the same trend as those examined in Villanova-de-Benavent et al. (2016) by transmission electron microscopy, as they yield relatively high $\mathrm{Ni}$ contents and have a high talc component.

In the limonite horizon, goethite exhibits substitution of $\mathrm{Fe}$ by $\mathrm{Al}$ (up to 22 wt. $\% \mathrm{Al}_{2} \mathrm{O}_{3}$; Figure 12a, Table 4) and $\mathrm{Ni}$ contents up to 2 wt. $\% \mathrm{NiO}$, although in most cases $\mathrm{Ni}$ contents are negligible (Figure 12b). The average content of $\mathrm{NiO}$ in goethite is close to $0.5 \mathrm{wt} . \%$. Analyses showing the highest $\mathrm{Ni}$ concentrations also show the highest amounts of $\mathrm{Co}$ (up to 0.6 wt. \% $\mathrm{CoO}$ ) and $\mathrm{Mn}$ (up to $5 \mathrm{wt} . \% \mathrm{MnO}$ ), these three elements being directly correlated (Figures 12c and 12d). The significant $\mathrm{Mn}$ content in the limonite horizon (Figure 5c) is explained by the abundance of Mn-oxy-hydroxides occurring as black sheets and plates. These oxy-hydroxides have a Mn content 
from 22 to 41 wt. $\% \mathrm{MnO}$, with an average of 37 wt. $\%$; a Co content from 2.6 to 13 wt. $\% \mathrm{CoO}$, with an average of 8 wt. $\%$; and a Ni content from 8 to 20 wt. $\%$ NiO, with an average of 15 wt. $\%$. In Table 4, three selected Mn-oxy-hydroxide analyses are given (for maximum values of $\mathrm{MnO}, \mathrm{NiO}$, and $\mathrm{CoO})$, as well as the average of all the analyses. Mn-oxy-hydroxides comprehend a set of different minerals, some of them with a poorly defined stoichiometry: lithiophorite (( $\left.\mathrm{Al}, \mathrm{Li}) \mathrm{MnO}_{2}(\mathrm{OH})_{2}\right)$, asbolane $(\mathrm{Co}, \mathrm{Ni})_{1-\mathrm{y}}\left(\mathrm{MnO}_{2}\right)_{2-\mathrm{x}}(\mathrm{OH})_{2-2 \mathrm{y}+2 \mathrm{x} n}\left(\mathrm{H}_{2} \mathrm{O}\right)$, lithiophorite-asbolane intermediates, cryptomelane $\left(\mathrm{KMn}^{4+}{ }_{6} \mathrm{Mn}_{2}{ }_{2} \mathrm{O}_{16}\right)$, and pyrochroite $\left(\mathrm{Mn}(\mathrm{OH})_{2}\right)$ (e.g., Roqué-Rosell et al., 2010). Accord- ing to their composition, Mn-oxy-hydroxides from Loma de Hierro have been mostly identified as lithiophorite-asbolane intermediates although some of them have a higher asbolane component (Figure 13). These lithiophorite-asbolane intermediates, together with lithiophorite, have also been identified in Moa Bay (Cuba), with values up to 22 wt.\% Ni (Roqué-Rosell et al., 2010; Aiglsperger et al., 2016), in New Caledonia with up to 15 wt. $\%$ $\mathrm{NiO}$ (Dublet et al., 2017), in Loma Ortega (Dominican Republic) with up to 23 wt. $\% \mathrm{NiO}$ (Tauler $e t$ al., 2017), and in Wingellina (Australia) (Putzolu et al., 2018). Since the crystal structures of these minerals (mostly asbolane) are not well known,
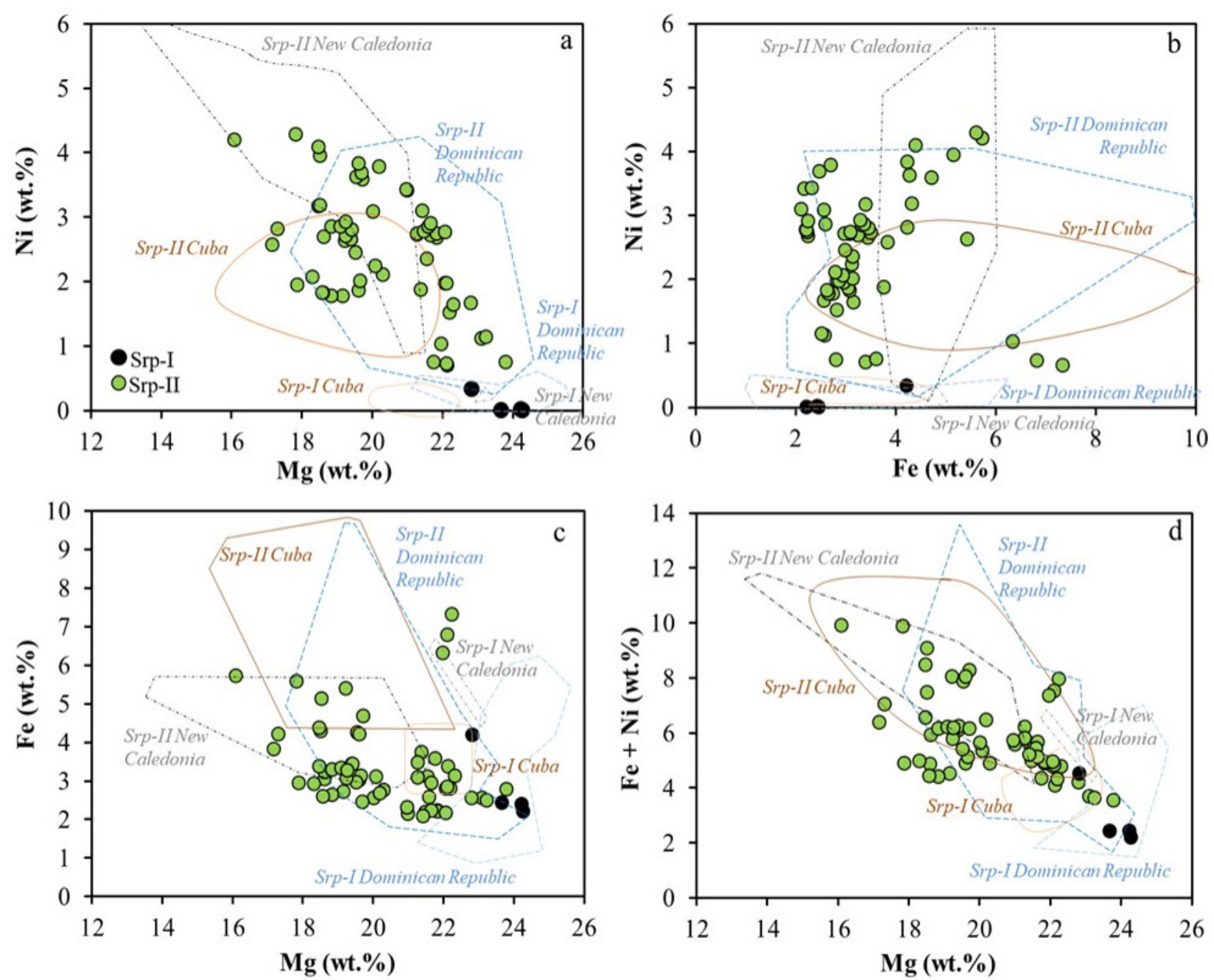

Figure 10 Comparison between the major octahedral elements in Srp-I and Srp-II in the samples of Loma de Hierro. (a) Ni-Mg. (b) Ni-Fe. (c) Fe-Mg. (d) Ni+Fe-Mg. Values are in wt.\%. Areas represent the values for Srp-I and Srp-II of Loma Ortega (Dominican Republic; Tauler et al., 2017), Indonesia (New Caledonia; Golightly and Arancibia, 1979), and Yamanigüey (Cuba; Villanova-de-Benavent et al., 2017). 
Table 3. Representative electron microprobe analyses (in wt.\%) and structural formulae (in atoms per formula unit, apfu) of Srp-I, SrpII and garnierites of Loma de Hierro samples. The molar percentage of talc-like phase (kerolite-pimelite) in the garnierite mixture is included (as calculated following the equation proposed by Soler et al., 2008).

\begin{tabular}{|c|c|c|c|c|c|c|c|c|c|c|c|c|c|c|c|}
\hline & \multicolumn{4}{|c|}{ Srp-I } & \multicolumn{8}{|c|}{ Srp-II } & \multicolumn{3}{|c|}{ Garnierite } \\
\hline Anal.No & 1 & 2 & 3 & 4 & 1 & 2 & 3 & 4 & 5 & 6 & 7 & 8 & 1 & 2 & 3 \\
\hline $\mathrm{SiO}_{2}$ & 42.53 & 42.10 & 43.01 & 39.27 & 41.97 & 42.25 & 42.08 & 40.54 & 42.46 & 39.30 & 40.98 & 42.12 & 44.41 & 44.93 & 46.57 \\
\hline $\mathrm{TiO}_{2}$ & 0.02 & 0 & 0 & 0.02 & 0.01 & 0.01 & 0.01 & 0.05 & 0 & 0.04 & 0 & 0 & 0 & 0 & 0 \\
\hline $\mathrm{Al}_{2} \mathrm{O}_{3}$ & 0.43 & 0.47 & 0.30 & 1.67 & 0.49 & 0.59 & 0.54 & 1.03 & 1.01 & 0.90 & 1.74 & 1.39 & 0 & 0.01 & 0 \\
\hline $\mathrm{Cr}_{2} \mathrm{O}_{3}$ & 0 & 0.02 & 0 & 0.78 & 0 & 0 & 0 & 0.57 & 0.56 & 0.47 & 1.11 & 0.87 & 0 & 0 & 0 \\
\hline $\mathrm{V}_{2} \mathrm{O}_{3}$ & 0 & 0.01 & 0.02 & 0.02 & 0 & 0 & 0 & 0.02 & 0 & 0.02 & 0 & 0.04 & 0.02 & 0 & 0 \\
\hline $\mathrm{Fe}_{2} \mathrm{O}_{3}$ calculated & . & - & - & - & 3.01 & 3.20 & 3.59 & 6.05 & 6.17 & 5.48 & 4.63 & 4.47 & 0.03 & 0.01 & 0.02 \\
\hline $\mathrm{FeO}$ & 3.11 & 3.16 & 2.85 & 5.42 & - & - & - & - & - & - & - & - & - & - & - \\
\hline $\mathrm{MnO}$ & 0.05 & 0.06 & 0.01 & 0.03 & 0.04 & 0.01 & 0.02 & 0.03 & 0.05 & 0.07 & 0.04 & 0.05 & 0.12 & 0.1 & 0.1 \\
\hline MgO & 40.16 & 39.23 & 40.22 & 37.83 & 35.49 & 35.88 & 38.51 & 28.68 & 30.67 & 28.44 & 30.85 & 33.27 & 14.06 & 14.26 & 16.63 \\
\hline $\mathrm{NiO}$ & 0.03 & 0.01 & 0.02 & 0.43 & 3.96 & 3.71 & 1.47 & 3.60 & 4.06 & 3.29 & 3.44 & 2.86 & 21.21 & 22.34 & 18.71 \\
\hline $\mathrm{CoO}$ & 0.01 & 0.01 & 0 & 0.01 & 0 & 0 & 0.01 & 0 & 0.01 & 0 & 0.01 & 0 & 0.02 & 0 & 0 \\
\hline $\mathrm{CaO}$ & 0.12 & 0.09 & 0.06 & 0.03 & 0.1 & 0.05 & 0 & 0.24 & 0.26 & 0.22 & 0.15 & 0.07 & 0.09 & 0.14 & 0.12 \\
\hline $\mathrm{Na}_{2} \mathrm{O}$ & 0.03 & 0.02 & 0.02 & 0.07 & 0.02 & 0.06 & 0.02 & 0.10 & 0.09 & 0.11 & 0.05 & 0.05 & 0.12 & 0.1 & 0.17 \\
\hline $\mathrm{K}_{2} \mathrm{O}$ & 0.03 & 0.02 & 0.02 & 0.02 & 0 & 0 & 0.01 & 0.03 & 0.03 & 0.03 & 0.04 & 0 & 0.1 & 0.11 & 0.08 \\
\hline Total & 86.52 & 85.20 & 86.53 & 85.60 & 85.09 & 85.76 & 86.26 & 80.94 & 85.37 & 78.37 & 83.04 & 85.19 & 80.18 & 82.00 & 82.40 \\
\hline O (str.form) & 7 & 7 & 7 & 7 & 7 & 7 & 7 & 7 & 7 & 7 & 7 & 7 & 11 & 11 & 11 \\
\hline Si & 2.004 & 2.013 & 2.020 & 1.910 & 2.034 & 2.029 & 1.993 & 2.078 & 2.068 & 2.077 & 2.040 & 2.035 & 3.838 & 3.816 & 3.839 \\
\hline $\mathbf{T i}$ & 0.001 & 0 & 0 & 0.001 & 0.000 & 0.000 & 0.000 & 0.002 & 0 & 0.002 & 0 & 0 & 0 & 0 & 0 \\
\hline Al & 0.024 & 0.026 & 0.017 & 0.096 & 0.028 & 0.033 & 0.030 & 0.062 & 0.058 & 0.056 & 0.102 & 0.079 & 0 & 0.001 & \\
\hline $\mathrm{Cr}$ & 0 & 0.001 & 0 & 0.030 & 0 & 0 & 0 & 0.023 & 0.022 & 0.020 & 0.044 & 0.033 & 0 & 0 & 0 \\
\hline $\mathbf{V}$ & 0 & 0.000 & 0.001 & 0.001 & 0 & 0 & 0 & 0.001 & 0 & 0.001 & 0 & 0.002 & 0.001 & 0.00 & 0.00 \\
\hline $\mathrm{Fe}(\mathrm{II})$ & 0.123 & 0.126 & 0.112 & 0.221 & - & - & - & - & - & - & - & - & - & - & - \\
\hline $\mathrm{Fe}$ (III) & & & & & 0.110 & 0.116 & 0.128 & 0.233 & 0.226 & 0.218 & 0.174 & 0.162 & 0.002 & 0.001 & 0.001 \\
\hline Mn & 0.002 & 0.002 & 0.000 & 0.001 & 0.002 & 0.000 & 0.001 & 0.001 & 0.002 & 0.003 & 0.002 & 0.002 & 0.009 & 0.007 & 0.007 \\
\hline Mg & 2.821 & 2.797 & 2.816 & 2.744 & 2.563 & 2.569 & 2.719 & 2.192 & 2.226 & 2.240 & 2.289 & 2.396 & 1.811 & 1.805 & 2.044 \\
\hline $\mathbf{N i}$ & 0.001 & 0.000 & 0.001 & 0.017 & 0.154 & 0.143 & 0.056 & 0.148 & 0.159 & 0.140 & 0.138 & 0.111 & 1.474 & 1.526 & 1.241 \\
\hline $\mathrm{Co}$ & 0.000 & 0.000 & 0 & 0.000 & 0 & & 0.000 & 0 & 0.000 & 0 & 0.000 & 0 & 0.001 & 00 & 0 \\
\hline $\mathrm{Ca}$ & 0.006 & 0.005 & 0.003 & 0.002 & 0.005 & 0.003 & 0.000 & 0.013 & 0.014 & 0.012 & 0.008 & 0.004 & 0.008 & 0.013 & 0.011 \\
\hline $\mathrm{Na}$ & 0.003 & 0.002 & 0.002 & 0.007 & 0.002 & 0.006 & 0.002 & 0.010 & 0.008 & 0.011 & 0.005 & 0.005 & 0.020 & 0.016 & 0.027 \\
\hline $\mathbf{K}$ & 0.002 & 0.001 & 0.001 & 0.001 & 0 & 0 & 0.001 & 0.002 & 0.002 & 0.002 & 0.003 & 0 & 0.011 & 0.012 & 0.008 \\
\hline$\%$ talc & & & & & & & & & & & & & 75.09 & 71.76 & 75.26 \\
\hline
\end{tabular}

they cannot be identified nor quantified by XRPD. However, the amount of Mn-oxy-hydroxides in limonite samples can be estimated to be around 3 wt. $\%$, by assuming both the whole rock (in wt. $\%$ $\mathrm{MnO}$ from XRF and ICP-MS analyses) and the mineral $\mathrm{MnO}$ content (in wt. $\% \mathrm{MnO}$ from EMPA analyses).

Scandium has been detected in some analyses of goethite, showing values up to 0.01 wt. $\%$ (100 $\mathrm{ppm})$, although in most of them Sc was below detection limit.

\section{Discussion}

Petrographic and mineralogical observations, as well as whole rock chemical analyses, permitted us to conclude that the protolith consists of mantle harzburgite tectonites that have experienced a plastic deformation at high temperatures. This harzburgite has been only slightly primarily serpentinized, so that in the saprolite horizon most phyllosilicates are secondary in origin. The transition from hard rock to saprolite is gradual, with joined blocks of harzburgite becoming sparser, and rounded corestones being found within the saprolite (i.e. sample A-14). Very often, these blocks are coated by garnierite.

\subsection{ELEMENTAL MOBILITY IN THE WEATHERING PROFILE}

In the protolith, the distribution of the relevant major element oxides among the main minerals indicate that $\mathrm{Mg}$ and $\mathrm{Si}$ are contained in forsterite, enstatite, and Srp-I; Fe is present in the above phases plus magnetite and $\mathrm{Cr}$-spinel; and $\mathrm{Al}$, very scarce $\left(1 \mathrm{wt} . \% \mathrm{Al}_{2} \mathrm{O}_{3}\right)$, is contained in minor 


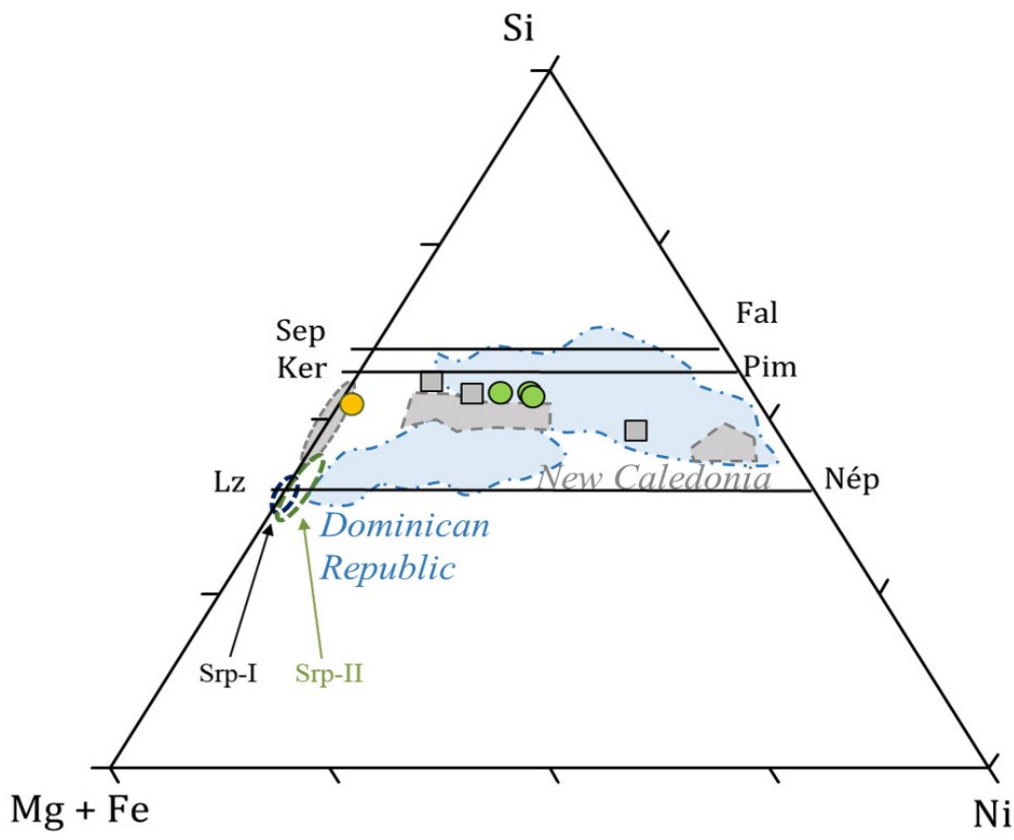

Figure 11 Ternary plot showing the electron microprobe analyses (EMPA) of selected garnierites of the saprolite horizon (green dots; modified from Villanova-de-Benavent et al., 2014; Sep = sepiolite, Fal = falcondoite, Ker = kerolite, Pim = pimelite, Lz = lizardite, Nép = népouite). Srp-I and Srp-II EMPA analyses have also been plotted for a sake of comparison. Si, Mg, Fe, and $\mathrm{Ni}$ are in atoms per formula unit. The shadowed area represents the compositional field of garnierites from the Falcondo mining area (Dominican Republic) from Tauler et al. (2017) and Villanova-de-Benavent et al. (2014) in blue and of garnierites from New Caledonia, from Cathelineau et al. (2016) in gray. Orange dot is garnierite composition of Loma de Hierro reported in Soler et al. (2008). Gray squares are New Caledonia garnierite compositions reported in Wells et al. (2009).

chlorite and Cr-spinel (both less than 1\% modal). The Fo/En molar ratio is about 3, indicating that complete serpentinization would yield an excess of forsterite, which will be eliminated by dissolution during the supergene stage.

Forsterite dissolution by acidic weathering, according to reaction 1 , results in an increase of porosity, even if silica were retained as an amorphous silica gel. This is reflected by the increase of the $\mathrm{Si} / \mathrm{Mg}$ molar ratio, from 0.7 in the protolith to 0.95 at the top of the saprolite horizon, near the $\mathrm{Mg}$ discontinuity.

$$
\mathrm{Mg}_{2} \mathrm{SiO}_{4}+4 \mathrm{H}^{+}=\mathrm{SiO}_{2}+2 \mathrm{Mg}^{2+}+2 \mathrm{H}_{2} \mathrm{O} \quad \text { r. } 1
$$

The preservation of rock structure in the saprolite suggests a replacement of forsterite and enstatite by serpentine (Srp-II) and/or kerolite. Assuming total retention of silica and maximum conservation of mass in the minerals (which is not the case), the net reactions from forsterite (dominant in the protolith) can be written as

$$
\begin{aligned}
& 2 \mathrm{Mg}_{2} \mathrm{SiO}_{4}+2 \mathrm{H}++\mathrm{H}_{2} \mathrm{O}= \\
& \mathrm{Mg}_{3} \mathrm{Si}_{2} \mathrm{O}_{5}(\mathrm{OH})_{4}+\mathrm{Mg}^{2+} \\
& 3 / 2 \mathrm{Mg}_{2} \mathrm{SiO}_{4}+5 / 2 \mathrm{SiO}_{2}(\mathrm{aq})+\mathrm{H}_{2} \mathrm{O}= \\
& \mathrm{Mg}_{3} \mathrm{Si}_{4} \mathrm{O}_{10}(\mathrm{OH})_{2} \\
& 3 \mathrm{MgSiO}_{3}+2 \mathrm{H}_{2} \mathrm{O}=\mathrm{Mg}_{3} \mathrm{Si}_{2} \mathrm{O}_{5}(\mathrm{OH})_{4}+\mathrm{SiO}_{2} \text { r. } 4 \\
& 3 \mathrm{MgSiO}_{3}+\mathrm{SiO}_{2}(\mathrm{aq})+\mathrm{H}_{2} \mathrm{O}= \\
& \mathrm{Mg}_{3} \mathrm{Si}_{4} \mathrm{O}_{10}(\mathrm{OH})_{2}
\end{aligned}
$$

The formation of serpentine (Srp-II) from forsterite and enstatite weathering according to r.2 and r.4, and that of kerolite, more favorable under higher $\mathrm{Si} / \mathrm{Mg}$ aqueous concentration ratios (Galí et al., 2012), (r.3, r.5), may explain the formation of the secondary phyllosilicate mixture identified in the field. 
Table 4. Representative electron microprobe analyses (in wt.\%) and structural formulae (in atoms per formula unit, apfu) of goethite and the asbolane-lithiophorite intermediate minerals of Loma de Hierro samples. The maximum content of $\mathrm{Mn}(\mathrm{Max}(\mathrm{Mn}))$, of $\mathrm{Ni}(\mathrm{Max}(\mathrm{Ni}))$ and of $\mathrm{Co}(\operatorname{Max}(\mathrm{Co}))$ is included in the asbolane-lithiophorite intermediate minerals, as well as the average analyses of all samples.

\begin{tabular}{|c|c|c|c|c|c|c|c|c|c|}
\hline & \multicolumn{5}{|c|}{ Goethite } & \multicolumn{4}{|c|}{ Asbolane-lithiphorite intermediate } \\
\hline Anal.No. & 1 & 2 & 3 & 4 & 5 & $\operatorname{Max}(\mathbf{M n})$ & $\operatorname{Max}(\mathbf{N i})$ & $\operatorname{Max}(\mathrm{Co})$ & Average \\
\hline $\mathrm{SiO}_{2}$ & 0.56 & 0.92 & 0.81 & 0.53 & 0.53 & 0.30 & 0.19 & 0.09 & 0.24 \\
\hline $\mathrm{Al}_{2} \mathrm{O}_{3}$ & 2.55 & 5.90 & 5.66 & 21.49 & 21.00 & 5.28 & 5.36 & 8.89 & 6.32 \\
\hline $\mathrm{CaO}$ & 0.05 & 0 & 0.01 & 0 & 0 & 0.05 & 0.04 & 0.05 & 0.04 \\
\hline $\mathrm{TiO}_{2}$ & 0 & 0.01 & 0.02 & 0.16 & 0.16 & 0.00 & 0.00 & 0.00 & 0.01 \\
\hline $\mathrm{Cr}_{2} \mathrm{O}_{3}$ & 0.17 & 0.31 & 0.37 & 1.04 & 1.21 & 0.00 & 0.00 & 0.00 & 0.06 \\
\hline $\mathrm{MgO}$ & 0.03 & 0.04 & 0 & 0 & 0.01 & 3.85 & 1.87 & 1.23 & 2.02 \\
\hline NiO & 0 & 0.28 & 0.19 & 0.02 & 0.04 & 16.41 & 20.23 & 11.57 & 14.71 \\
\hline $\mathrm{CoO}$ & 0.13 & 0.11 & 0.11 & 0.08 & 0.09 & 6.95 & 4.00 & 12.60 & 7.99 \\
\hline $\mathrm{FeO}$ & 0.00 & 0.00 & 0.00 & 0.00 & 0.00 & 0.00 & 0.00 & 0.00 & 0.00 \\
\hline $\mathrm{MnO}$ & 0.01 & 0.10 & 0.02 & 0.01 & 0 & 40.73 & 40.73 & 39.14 & 37.31 \\
\hline $\mathrm{V}_{2} \mathrm{O}_{3}$ & 0.00 & 0.05 & 0.05 & 0.01 & 0.01 & 0.00 & 0.02 & 0.00 & 0.00 \\
\hline $\mathrm{Sc}_{2} \mathrm{O}_{3}$ & 0 & 0 & 0 & 0 & 0 & 0.00 & 0.00 & 0.00 & 0.00 \\
\hline $\mathrm{Fe}_{2} \mathrm{O}_{3}$ & 85.58 & 81.25 & 81.54 & 66.77 & 65.65 & 6.40 & 7.62 & 0.00 & 4.90 \\
\hline Total & 89.08 & 88.97 & 88.77 & 90.11 & 88.70 & 79.97 & 80.06 & 73.57 & 73.61 \\
\hline O (str.form) & 1.5 & 1.5 & 1.5 & 1.5 & 1.5 & & & & \\
\hline Si & 0.008 & 0.013 & 0.012 & 0.007 & 0.007 & & & & \\
\hline Al & 0.044 & 0.099 & 0.096 & 0.328 & 0.325 & & & & \\
\hline $\mathbf{C a}$ & 0.001 & 0 & 0.000 & 0 & 0 & & & & \\
\hline $\mathbf{T i}$ & 0 & 0.000 & 0.000 & 0.002 & 0.002 & & & & \\
\hline $\mathrm{Cr}$ & 0.002 & 0.003 & 0.004 & 0.011 & 0.013 & & & & \\
\hline Mg & 0.001 & 0.001 & 0 & 0 & 0.000 & & & & \\
\hline $\mathbf{N i}$ & 0 & 0.003 & 0.002 & 0.000 & 0.000 & & & & \\
\hline Co & 0.002 & 0.001 & 0.001 & 0.001 & 0.001 & & & & \\
\hline Mn & 0.000 & 0.001 & 0.000 & 0.000 & 0 & & & & \\
\hline $\mathbf{V}$ & 0.000 & 0.001 & 0.001 & 0.000 & 0.000 & & & & \\
\hline Se & 0 & 0 & 0 & 0 & 0 & & & & \\
\hline $\mathrm{Fe}(\mathrm{III})$ & 0.941 & 0.874 & 0.881 & 0.650 & 0.649 & & & & \\
\hline
\end{tabular}

The newly formed Srp-II is quite different from Srp-I. Srp-I, which is only observed in the protolith, indicating that its composition is essentially unstable in weathering conditions, is Al-poor, and has half the Fe and more than one order of magnitude less $\mathrm{Ni}$ compared to either the coexisting forsterite or enstatite (Table 2). In the saprolite horizon, Srp-II is enriched in Fe by a factor of 1.5 (from 3 to 5 wt. $\% \mathrm{FeO}$ ) and in $\mathrm{Ni}$ by more than two orders of magnitude (from 0.02 to $6 \mathrm{wt} . \%$ $\mathrm{NiO}$ ) compared to Srp-I. It has been shown (for a review, see for instance Villanova-de-Benavent $e t$ al., 2017) that this change in composition stabilizes serpentine in the lateritic environment. In particular, Srp-II may be described as a three-component solid solution of the end members lizardite, $\mathrm{Mg}_{3} \mathrm{Si}_{2} \mathrm{O}_{5}(\mathrm{OH})_{4}$, népouite $\mathrm{Ni}_{3} \mathrm{Si}_{2} \mathrm{O}_{5}(\mathrm{OH})_{4}$, and $\mathrm{Fe}(\mathrm{III})$-serpentine $\mathrm{Fe}_{2} \mathrm{Si}_{2} \mathrm{O}_{5}(\mathrm{OH})_{4}$, that lowers the equilibrium constant for dissolution by 2 to $5 \mathrm{log}$
$\mathrm{K}$ units. The detailed mechanism of formation of such a solid solution is controversial.

$\mathrm{Fe}$ released in the dissolution of olivine and pyroxene precipitates as $\mathrm{Fe}(\mathrm{III})$-oxy-hydroxides. Magnetite is also frequently oxidized to goethite afterwards (r.6).

$$
\mathrm{Fe}_{3} \mathrm{O}_{4}+3 / 2 \mathrm{H}_{2} \mathrm{O}+1 / 4 \mathrm{O}_{2}=3 \mathrm{FeOOH} \text { r.6 }
$$

The transition to the limonite horizon is marked by a clear Mg-discontinuity (Figure 4). This limonite horizon concentrates the highly insoluble elements $\mathrm{Fe}, \mathrm{Al}$, and $\mathrm{Cr}$ included in inherited minerals that resisted weathering, such as magnetite and Cr-spinel, or in newly formed phases such as goethite, hematite, and gibbsite (Figure 4, Table 1).

SEM images show an astonishing variety of microstructures and reactions in all these minerals, which include several processes of cementation of 
quartz by oxy-hydroxides, alteration of $\mathrm{Cr}$-spinel (post-magmatic), transformation of goethite to hematite and vice versa, phyllosilicates pseudomorphed by goethite and gibbsite, and a variety of mixtures of amorphous Fe-oxy-hydroxides (Figures $8 \mathrm{~g}$ and $8 \mathrm{~h}) . \mathrm{Mn}$ is retained in black, poorly crystalline nodules identified as minerals of the lithiophorite-asbolane series and asbolane (Figure 9h).

The remarkable $\mathrm{Al}_{2} \mathrm{O}_{3}$ content in the limonite horizon, which is related to the high amount of gibbsite detected by XRPD, has also been observed in other Ni-laterites worldwide [ $(e . g$., the hydrous $\mathrm{Mg}$ silicate-type deposits of Cerro Matoso, Colombia (Gleeson et al., 2004) and Loma Caribe and Loma Peguera, Dominican Republic (Aiglsperger et al., 2016), and the oxide-type laterites of Nkamouna, Cameroon (Lambiv Dzemua et al., 2013) and Moa Bay, Cuba (Aiglsperger et al., 2016)]. In all cases, the protolith is not substantially rich in $\mathrm{Al}\left(<2\right.$ wt. $\left.\% \mathrm{Al}_{2} \mathrm{O}_{3}\right)$, but the $\mathrm{Al}$ content increases upwards in the profile. In particular, $\mathrm{Al}_{2} \mathrm{O}_{3}$ reaches $6-10$ wt. $\%$ in the ferricrete and $8-10$ wt. $\%$ in the limonite of Cerro Matoso, 32 wt. $\%$ in the ferricrete and $10-23$ wt. $\%$ in the limonite of Loma Caribe, 26 wt. $\%$ in the ferric-
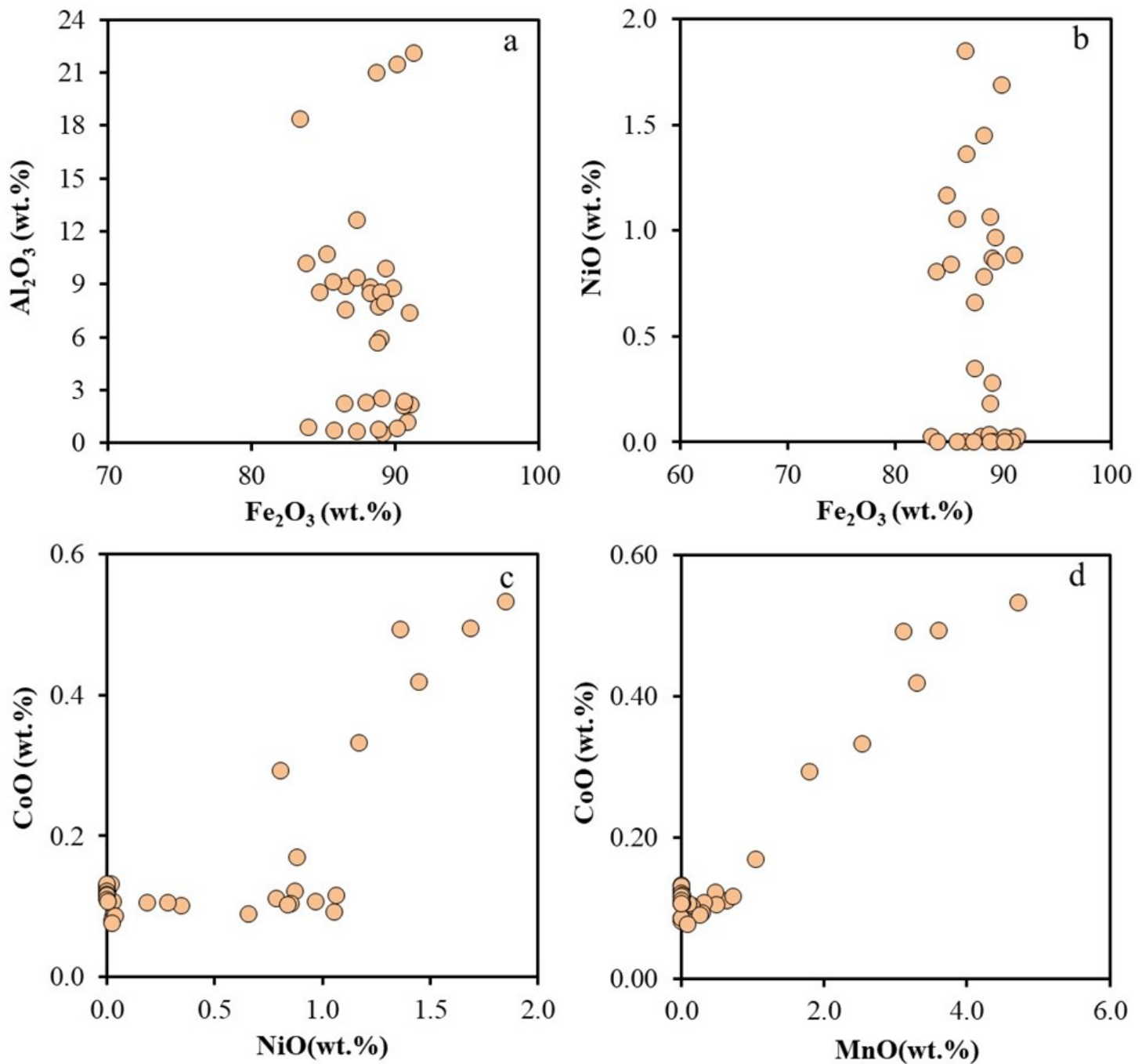

Figure 12 Element correlation in goethite from EMPA analyses. (a) $\mathrm{Fe}_{2} \mathrm{O}_{3}-\mathrm{Al}_{2} \mathrm{O}_{3^{*}}$ (b) $\mathrm{Fe}_{2} \mathrm{O}_{3}-\mathrm{NiO}$. (c) $\mathrm{NiO}-\mathrm{CoO}$. (d) $\mathrm{MnO}-\mathrm{CoO}$. From the samples of Loma de Hierro. Values are in wt.\%. 
rete and 4 wt. $\%$ in the limonite of Loma Peguera, 20-25 wt. $\%$ in the limonite and ferricrete breccia of Nkamouna, and $15 \mathrm{wt} . \%$ in the duricrust and 8-10 wt.\% of the limonite of Moa Bay. This is correlated with important amounts of gibbsite and kaolinite (e.g., up to 22 wt.\% gibbsite in the ferricrete and 7 wt.\% kaolinite in "tachylite" of Cerro Matoso). In Cerro Matoso, the protolith is a lherzolite with harzburgite and dunite, containing forsteritic olivine, orthopyroxene, and clinopyroxene. In the Dominican laterites, the protolith is mainly harzburgite and dunite, and in Moa Bay, it is harzburgite. Hence, they may all contain significant amounts of Al-bearing pyroxene, explaining the higher $\mathrm{Al}$ contents, which, together with $\mathrm{Fe}$, $\mathrm{Ni}, \mathrm{Co}$, and $\mathrm{Mn}$, would ultimately concentrate in the upper horizon.

The overall REE contents in the Ni-laterites are very low when compared to conventional REE ore deposits (e.g., Chakhmouradian and Wall, 2012), but they are similar to REE contents measured in other laterite deposits of the Caribbean area. In Moa Bay (Cuba), $\sum$ REE concentrations are low in the unweathered harzburgite $(\sim 0.1$ $\mathrm{ppm})$, vary from 1 to $3 \mathrm{ppm}$ in the saprolite, and are higher in the limonite (15 to $68 \mathrm{ppm}$ ) (Aiglsperger et al., 2016). In Loma Caribe (Falcondo, Dominican Republic), the parent rock contains $0.6 \mathrm{ppm}$ ¿REE, the saprolite contains 0.9 to 1.6 ppm $\sum$ REE, and the limonite concentrates 37 to 335 ppm $\sum$ REE. In Loma Peguera, the contents of REE in the parent rock, saprolite, and limonite horizons are $0.2,0.5$ to 6 , and 122 to $171 \mathrm{ppm}$ $\sum$ REE, respectively (Aiglsperger et al., 2016). In all cases, REE contents in saprolite and limonite horizons are enriched with respect to the protolith, as a result of the decomposition of REE-bearing minerals due to the weathering process. REE aqueous complexes move down the profile but are removed from the aqueous phase by mineral precipitation or sorption processes once $\mathrm{pH}$ increases.

However, note that in Loma de Hierro, the highest $\sum$ REE contents (up to $81 \mathrm{ppm}$ ) are found in the upper saprolite horizon, just below the limonite horizon, while in the aforementioned Caribbean laterites and in other deposits such as Wingellina Ni-Co oxide-type laterite deposit (Australia) REE are mainly concentrated in the limonite horizon (e.g., Aiglsperger et al., 2016; Putzolu et al., 2019). Aiglsperger et al. (2016) and Putzolu et al. (2019)
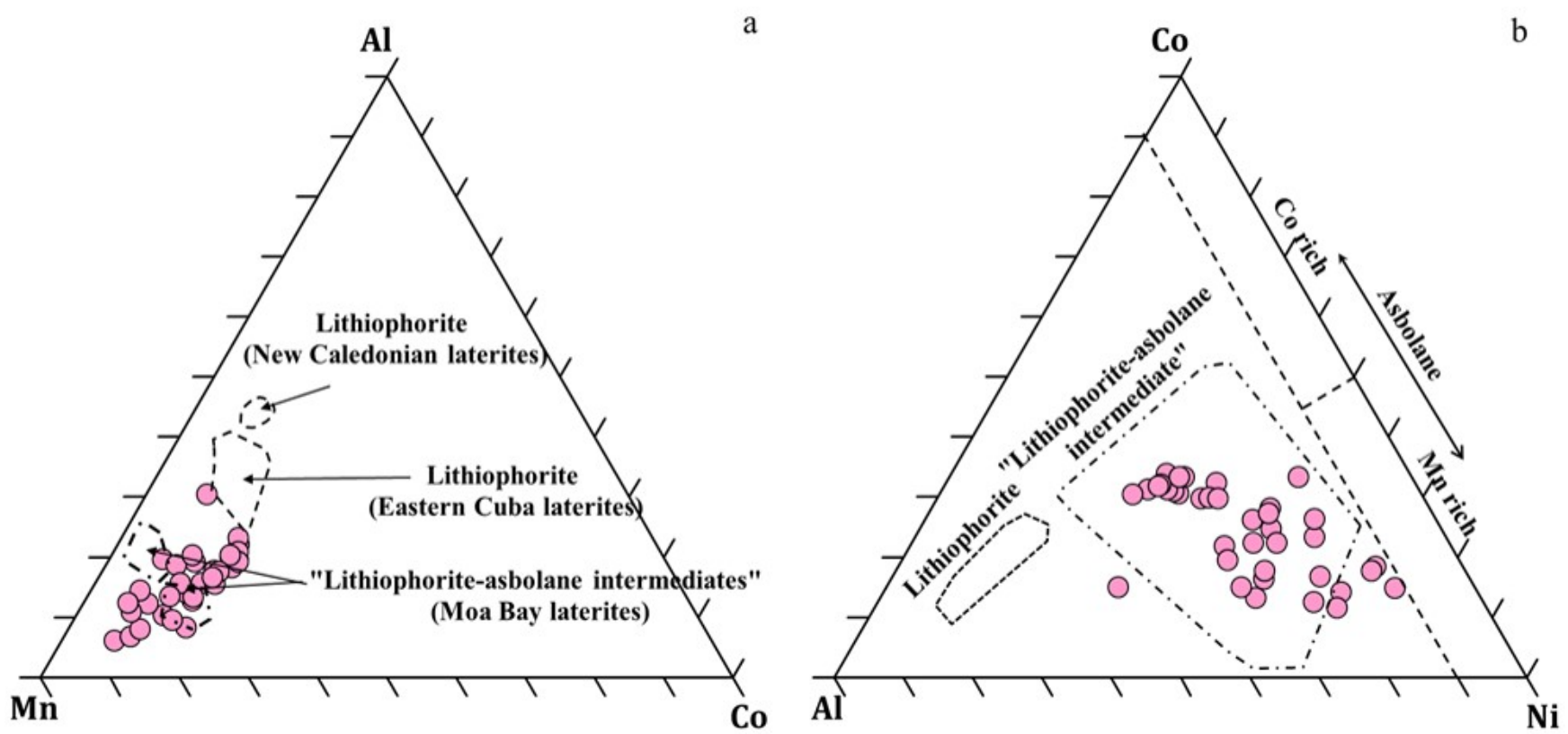

Figure 13 Ternary diagrams showing the compositions of Mn-oxy-hydroxides analyzed with electron microprobe analyses (EMPA). (a) Mn-Al-Co. (b) Al-Co-Ni. Modified from Roqué-Rosell et al., 2010. 
observed a positive correlation between REE and $\mathrm{MnO}$ or $\mathrm{Fe}_{2} \mathrm{O}_{3}$ content in the limonite horizon. In Loma de Hierro, despite the highest REE concentration in the saprolite horizon, this correlation is also observed (Figures 5c and 5d) suggesting that REE can accumulate in Fe/Mn-bearing oxy-hydroxides. These oxides have been identified, and despite being in low amount, the preferential Fe/ Mn-oxy-hydroxides scavenging of LREE instead of HREE (due to the highest stability of HREE-humic acids aqueous complexes) may explain the negative continuous slope for LREE observed in Figure 6 (Sanematsu and Watanabe, 2016). Moreover, in this limonite horizon, there is a slight positive Ge anomaly, which indicates the oxidation of $\mathrm{Ce}(\mathrm{III})$ to $\mathrm{Ce}(\mathrm{IV})$ and probably precipitation of $\mathrm{Ce}(\mathrm{IV})$ solid phases under the oxidizing conditions prevailing in this horizon (e.g., Aigslperger et al., 2016 and references therein). Ce content positively correlates with $\mathrm{Fe}_{2} \mathrm{O}_{3}$ (Table 1), which is coherent with the $\mathrm{Ce}$ fractionation and concentration in the upper horizons of the deposit (Mongelli et al., 2014). The REE accumulation at the top of a developed saprolite horizon with significant negative Ce anomalies below a thin REE-leached zone with positive Ce anomalies, as observed in Loma de Hierro, is similar to the ion-adsorption-type REE deposits of China described in Sanematsu and Watanabe (2016). These deposits developed over granites and are characterized by REE being preferentially sorbed onto kaolinite and similar minerals. According to Sanematsu and Watanabe (2016) and references therein, REE fractionation due to sorption is negligible at the ionic strength of soil water, and this would explain the planar slope observed in Figure 6. However, more information is needed to locate the mineralogy of REE, and to constrain the weathering conditions that occurred in the Venezuelan laterites. In addition, more data on worldwide distribution of REE in oxide, clay, and hydrous $\mathrm{Mg}$ silicate-type Ni-laterites, together with a detailed mineralogical characterization, is paramount.

Co contents are linked to Mn contents (Figure 12d) as in other laterite deposits (Llorca and Mon- choux, 1991; Roqué-Rosell et al., 2010; Lambiv Dzemua et al., 2013; Aiglsperger et al., 2016; Putzolu et al., 2019). However, while in Moa Bay and Falcondo the $\mathrm{Mn}-\mathrm{Co}$ association is mainly found in the upper saprolite, in Wingellina, as in Loma de Hierro, the most significant contents of $\mathrm{Mn}$ and Co are found in the limonite horizon. According to Putzolu et al. (2019), precipitation of Mn-oxy-hydroxides is controlled by the variation of $\mathrm{Eh}$ and $\mathrm{pH}$ in the profile. Accumulation of Mn-oxy-hydroxides in the transition between saprolite and limonite horizons has been frequently described (Brand et al. 1998). Dublet et al. (2017) suggested that weathering of the protolith promotes the oxidation of $\mathrm{Mn}(\mathrm{II})$ to $\mathrm{Mn}$ (III) and finally to $\mathrm{Mn}(\mathrm{IV})$, which precipitates forming Mn-oxy-hydroxides rather than being incorporated into goethite. This precipitation seems to be favored by a high humidity and an alkaline $\mathrm{pH}$, conditions that are likely to be found at some depth from the surface, close to the $\mathrm{Mg}$ discontinuity.

Sc contents in the limonite horizon of Loma de Hierro (40-70 ppm) are not as high as values reported by Aiglsperger et al. (2016) in Moa Bay (Cuba) and Falcondo (Dominican Republic) laterites (70-80 ppm and higher) or by Teitler et al. (2019) in New Caledonia (40-100 ppm). However, they are similar to those measured in laterites from New Caledonia (up to 70 ppm; Audet (2008) in Aiglsperger et al., 2016), Oman (35-85 ppm; Al-Khirbash, 2016), and Australia (13-80 ppm; Putzolu et al., 2019). In the Australian laterites, however, higher Sc concentrations were measured in the saprolite horizon, contrary to that observed in this study and in the other cited references.

$\mathrm{Sc}$ is considered to be initially present in pyroxene in the peridotite (Aiglsperger et al., 2016; Teitler et al., 2019), substituting for ferrous iron and later concentrating in $\mathrm{Fe}(\mathrm{III})$-bearing minerals during laterization. This association with $\mathrm{Fe}(\mathrm{III})$ has also been observed in a lateritic deposit in eastern Australia (Chassé et al., 2017) and in a bauxite deposit in Greece (Vind et al., 2018). Sc may substitute for $\mathrm{Fe}(\mathrm{III})$ in the goethite structure (Levard et al., 2018; Ulrich et al. 2019) 
or be sorbed onto Fe-oxides minerals (Chassé et al., 2017), but after recrystallization of goethite to hematite, Sc concentrates downwards leading to further Sc enrichment (Teitler et al., 2019). Putzolu et al. (2019) suggested that Sc may also substitute for $\mathrm{Fe}(\mathrm{III})$ in $\mathrm{Fe}(\mathrm{III})$-bearing layered silicates (e.g., montmorillonite or chlorite), although more studies must be done to clarify this point. In this study, only a few EMPA measurements have shown Sc in goethite. Considering its low concentration and the complexity of Fe-oxyhydroxide texture and crystallinity, more efforts should be focused (e.g., dedicated LA-ICP-MS analyses) on the mineralogy of Sc, and to better determine Sc contents in given minerals in order to improve the $\mathrm{Sc}$ extraction methods.

\subsection{MINERALOGY OF Ni}

In the harzburgitic protolith, $\mathrm{Ni}$ is mainly found in forsterite with values lower than 0.41 wt. $\% \mathrm{NiO}$; also $\mathrm{Ni}$ content in enstatite is below $0.21 \mathrm{wt} . \%$ $\mathrm{NiO}$, while Srp-I is very poor in $\mathrm{Ni}(<0.04$ wt. $\%$
$\mathrm{NiO})$. As seen in Figure 4, the most Ni-enriched horizon in Loma de Hierro is the saprolite horizon. This horizon is rich in Srp-II, with NiO contents close to 6 wt. $\%$. Moreover, kerolite-pimelite dominated garnierites are also present, with $\mathrm{Ni}$ contents as high as 22 wt.\% NiO. Goethite, the main constituent of the limonite horizon, is poorer in $\mathrm{Ni}$, showing a mean $\mathrm{NiO}$ content of $0.5 \mathrm{wt} . \%$, although in some cases it can reach values of 2 wt.\%. Meanwhile, Mn-oxy-hydroxides have, in general, higher $\mathrm{Ni}$ contents $(\sim 15$ wt. $\% \mathrm{NiO})$. Assuming this average $\mathrm{NiO}$ content and that the estimated amount of these Mn-oxy-hydroxides in the samples is 3 wt. $\%$, Mn-oxy-hydroxides would account for approximately $80 \%$ of the $\mathrm{NiO}$ contained in the limonite horizon.

According to the classification of Ni-laterites by Brand et al. (1998) and Butt and Cluzel (2013), which is based on the principal Ni-bearing minerals, the Loma de Hierro deposit can be classified as a hydrous $\mathrm{Mg}$ silicate-type, which is consistent with the thickness of the saprolite horizon compared to that of the limonitic horizon (Figure a) AF-S-M plot

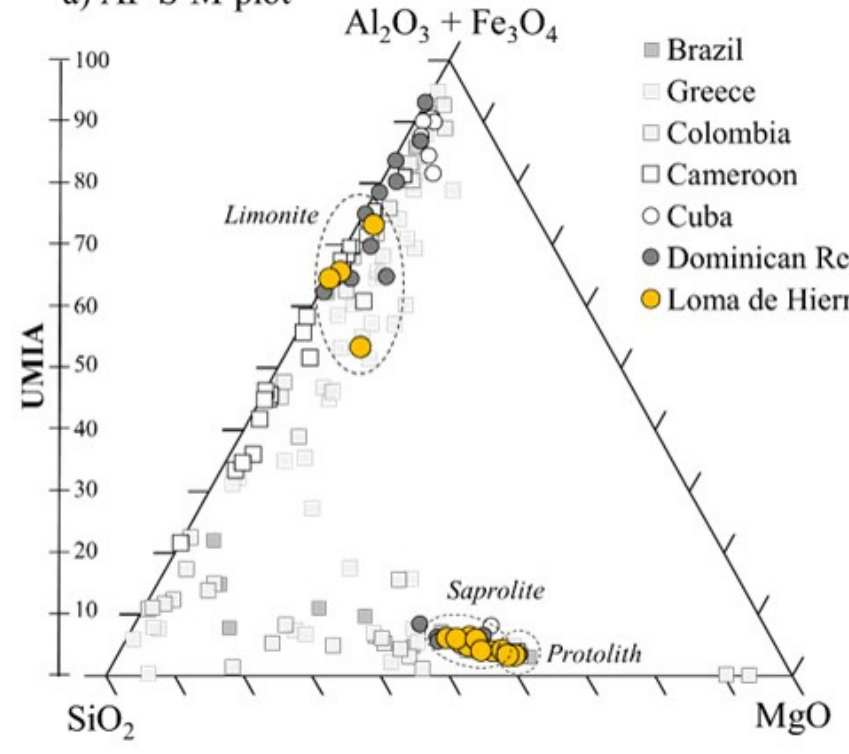

b) A-SM-F plot

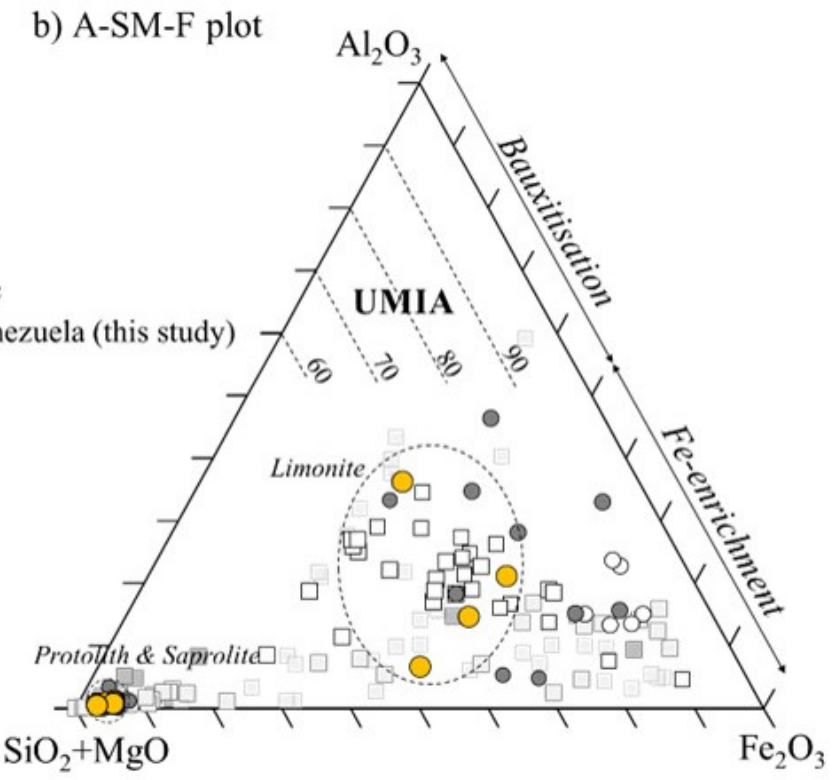

Figure 14 Molar ternary plots in the Al-Fe-Mg-Si space showing the weathering trends of ultramafic rocks and the ultramafic index of alteration (UMIA), with data from this study and from Brazil (Colin et al., 1990), Greece (Eliopoulos and Economous-Eliopoulos, 2000), Colombia (Gleeson et al., 2004), Cameroon (Ndjigui et al., 2008; Ndjigui and Bilong, 2010), and Cuba and Dominican Republic (Aiglsperger et al., 2016). (a) AF-S-M ternary plot illustrating the general weathering trend of peridotites with initial loss of MgO followed by loss of $\mathrm{SiO}_{2}$, and concomitant enrichment of $\mathrm{Al}_{2} \mathrm{O}_{3}$ and $\mathrm{Fe}_{2} \mathrm{O}_{3}$. (b) A-SM-F ternary plot illustrating the weathering trend with respect to $\mathrm{Al}_{2} \mathrm{O}_{3}$ enrichment (bauxitization) or $\mathrm{Fe}_{2} \mathrm{O}_{3}$ enrichment. 
4). Fe and Ni contents in Srp-II are comparable with those of other Caribbean hydrous $\mathrm{Mg}$ silicate deposits. In the Yamanigüey deposit (Cuba), developed on serpentinized harzburgite and dunite, $\mathrm{Ni}$ and Fe contents in Srp-II are in the ranges 1.99-4.72 wt. \% $\mathrm{NiO}$ and 2.2-15.6 wt. \% $\mathrm{Fe}_{2} \mathrm{O}_{3}$; while in Loma Caribe, from the Falcondo mining area (Dominican Republic) and developed on a serpentinized harzburgite, $\mathrm{Ni}$ and $\mathrm{Fe}$ contents in Srp-II range from 1.8 to $7 \mathrm{wt} . \% \mathrm{NiO}$ and from 3.8 to 13.5 wt. $\% \mathrm{Fe}_{2} \mathrm{O}_{3}$ (Villanova-de-Benavent et al., 2017). The contents of $\mathrm{NiO}$ in Srp-II and kerolite-pimelite dominated garnierites in Loma de Hierro are also similar to those measured in the Loma Ortega deposit, also from the Falcondo area and classified as a hybrid-hydrous $\mathrm{Mg}$ silicate-clay deposit $(<2.5$ wt. $\%$ NiO in Srp-II and 23-36 wt. $\%$ $\mathrm{NiO}$; Tauler et al. 2017).

\subsection{GONTROLS ON THE FORMATION OF THE WEATHERING PROFILE}

As stated by many authors (Golightly, 1981, 2010; Freyssinet et al., 2005; Butt and Cluzel, 2013), the main factors governing the formation and evolution of Ni-laterites are the parent rock (mineral composition, degree of initial serpentinization), climate (temperature, rainfall), water table, topography (hills, slopes, plateau), tectonics (uplift, fractures), and age (exposure time). The present climatic conditions in Loma de Hierro are characteristic of a semi-humid tropical high forest, with annual precipitation of $950 \mathrm{~mm}$ and mean temperature of $19{ }^{\circ} \mathrm{C}$, with a dry season from December to March. Tectonic uplift has been important, probably early after the emplacement of the ophiolitic unit, which represents an exposure period lasting for several My. Its altitude $(\sim 1300$ m.a.s.l.) combined with rather high erosion rates has resulted in a mountainous relief, with slopes up to $25^{\circ}\left(46^{\circ} \%\right)$.

In the studied profile, the $\mathrm{Mg}$ discontinuity is also a marked physical discontinuity as there is an irregular, sharp surface (Figure 3a) between the saprolite and limonite horizons, easily seen by the contrasting color and the change in the mechanical consistency, texture and mineralogical composition of the materials. This irregular surface suggests that erosion left the terrane exposed and the residual inconsistent limonite material was locally removed and redeposited, replenishing the depressed areas of the eroded surface, where fragments of duricrust (ferricrete) can be found. As seen in Figure 7, the amount of Mg-bearing secondary minerals (e.g. kerolite) is still high at the upper saprolite, consistent with a significant mechanical erosion. After uplift rejuvenated the relief during important elapsed time periods, erosion transported weathered material downwards, being erosion the dominant process. However, when uplift ceased, weathering became the dominant process and the eroded surface was covered again by limonite material. The blocks of fractured harzburgite, separated by several centimeters, are often coated by garnierite that may have precipitated due to oversaturation of the percolating solutions, perhaps more accentuated during the dry periods.

The ultramafic index of alteration (UMIA), defined by equation 1 (Aiglsperger et al., 2016; inspired by the mafic index of alteration (MIA) by Babechuk et al., 2014), has been calculated for each sample and is shown in Table 1. UMIA for the protolith in Loma de Hierro has a value of 3 while that of saprolite samples is around 6, consistent with values for unweathered peridotites and saprolites shown by Aiglsperger et al. (2016) in laterites of Moa Bay (Cuba) and Falcondo (Dominican Republic) (Figure 14a). Limonite samples of Loma de Hierro, however, show values from 53 to 73, slightly lower than those calculated by Aiglsperger et al. (2016) in the Caribbean area (Figures 14a and 14b).

$\mathrm{UMIA}=100 \times\left[\left(\mathrm{Al}_{2} \mathrm{O}_{3}+\mathrm{Fe}_{2} \mathrm{O}_{3}\right) /\left(\mathrm{Al}_{2} \mathrm{O}_{3}+\mathrm{Fe}_{2} \mathrm{O}_{3}\right.\right.$ $\left.\left.+\mathrm{SiO}_{2}+\mathrm{MgO}\right)\right] \quad$ eq. 1

Although there is a clear loss of $\mathrm{Mg}$ and $\mathrm{Si}$ in the upper parts of the profile, the enrichment in Fe in Loma de Hierro laterite is not as high as in other laterites. 


\section{Conclusions}

The Loma de Hierro Ni-laterite deposit has been classified as a hydrous- $\mathrm{Mg}$-silicate-type deposit, developed from a partially serpentinized harzburgitic peridotite $(<0.7$ wt. $\% \mathrm{NiO})$. The saprolite horizon is relatively thick $(\sim 17 \mathrm{~m})$ compared to the poorly developed limonite horizon $(>3 \mathrm{~m})$ and contains the main Ni-bearing minerals, Srp-II (1.4-4.1 wt. $\% \mathrm{NiO})$ and kerolite-pimelite dominated Ni-rich garnierite mixtures ( 22 wt. $\% \mathrm{NiO})$. The limonite horizon is rich in goethite $(\sim 0.5 \mathrm{wt} . \%$ $\mathrm{NiO})$ and Mn-oxy-hydroxides ( 15 wt. $\% \mathrm{NiO})$ which have been classified as lithiophorite-asbolane intermediates and asbolanes.

The highest contents of $\mathrm{Co}\left(0.19\right.$ wt. $\left.\% \mathrm{Co}_{3} \mathrm{O}_{4}\right)$ and Sc (40-70 ppm) are found in the limonite horizon, but while Co is clearly associated with the Mn-oxy-hydroxides in this horizon, Sc seems to be associated with Fe-oxy-hydroxides. Differing from other Caribbean laterite deposits, the highest REE contents are found in the upper saprolite horizon (81 ppm), below the $\mathrm{Mg}$ discontinuity, instead of being in the limonite horizon (40 ppm). REE data from the limonite horizon suggest that they are sorbed or coprecipitated within Fe-oxy-hydroxides. In the saprolite this link is not observed. A Ce negative anomaly in the saprolite horizon suggests the scavenging of $\mathrm{Ce}$ in the limonite horizon by precipitation as a $\mathrm{Ce}(\mathrm{IV})$ phase and explains the higher content of Ce in limonite than in the saprolite. More studies should be done to better clarify the location of $\mathrm{Co}$ and $\mathrm{Sc}$ in the limonite horizon and of REE in the saprolite of Loma de Hierro.

The combination of high erosion rates with sequential uplifts periods could have facilitated the removal and transport of the already formed limonite material, exposing again the saprolite to weathering and resulting in a poorly developed limonite horizon and a well-defined $\mathrm{Mg}$ discontinuity.

\section{Acknowledgements}

The authors thank the personnel from Minera Loma de Níquel for permission to access the mine and assistance in the field. They also thank the staff of the Centres Científics i Tecnològics of the Universitat de Barcelona, Barcelona (Spain) (CCiT-UB) for their assistance in measurements. This study was partially financed by the Caribbean Lithosphere Reserve Group (http:/ / caribbeanlithos.com/) and the Spanish Project PID2019105625RB-C21. We are grateful to Prof. Carl E. Nelson, F. Putzolu, and an anonymous reviewer for their careful reviews and constructive criticism of the original manuscript.

\section{References}

Aiglsperger, T., Proenza, J.A., Lewis, J.F., Labrador, M., Svojtka, M., Rojas-Purón, A., Longo, F., Durisova, J., 2016, Critical metals (REE, $\mathrm{Sc}, \mathrm{PGE}$ ) in Ni-laterites from Cuba and the Dominican Republic: Ore Geology Reviews, 73, 127-147. https://doi.org/10.1016/j. oregeorev.2015.10.010

Al-Khirbash, S.A., 2016, Geology, mineralogy, and geochemistry of low grade Ni-lateritic soil (Oman Mountains, Oman): Chemie der Erde, 76, 363-381. https://doi. org/10.1016/j.chemer.2016.08.002

Anders, E., Grevesse, N., 1989, Abundances of the elements: meteoritic and solar: Geochimica et Cosmochimica Acta 53, 197-214. https:// doi.org/10.1016/0016-7037(89)90286-X

Audet, M. A., 2008, Le massif du KoniamboNouvelle Calédonie: Formation et obduction d'un complexe ophiolitique de type SSZ. Enrichissement en nickel, cobalt et scandium dans les profils résiduels: Sciences de la Terre. Université de Nouvelle Calédonie,Doctoral dissertation,327 p.

Babechuk, M.G., Widdowson, M., Kamber, B.S., 2014, Quantifying chemical weathering intensity and trace element release from two contrasting basalt profiles, Deccan Traps, India: Chemical Geology363, 56-75.https:/ / doi.org/10.1016/j.chemgeo.2013.10.027

Brand, N.W., Butt, G.R.M., Elias, M., 1998, Nickel laterites: classification and features. 
AGSO: Journal of Australian Geology \& Geophysics, 17:81-88.

Brindley, G.W., 1978, The structure and chemistry of hydrous nickel containing silicate and aluminate minerals: Bulletin BRGM, Sec II (Géol Appl), 3, 233-245.

Butt, C.R.M., Cluzel, D., 2013, Nickel laterite ore deposits: weathered serpentinites: Elements, 9, 123-128. https://doi.org/10.2113/ gselements.9.2.123

Cathelineau, M., Quesnel, B., Gautier, P., Boulvais, P., Couteau, C., Drouillet, M., 2016, Nickel dispersion and enrichment at the bottom of the regolith: formation of pimelite targetlike ores in rock block joints (Koniambo $\mathrm{Ni}$ deposit, New Caledonia): Mineral Deposita 51, 271-282. https://doi.org/10.1007/ s00126-015-0607-y

Chakhmouradian, A.R., Wall, F., 2012, Rare earth elements: rare earth elements: minerals, mines, magnets (and more): Elements 8, 333-340. https://doi.org/10.2113/ gselements.8.5.333

Chassé, M., Griffin W.L., O’Reilly S.Y., Calas G., 2017, Scandium speciation in a world-class lateritic deposit: Geochemical Perspectives Letters 3, 105-114. https://doi.org/10.7185/ geochemlet.1711

Chassé, M., Griffin, W.L., O’Reilly, S.Y., Calas, G., 2019, Australian laterites reveal mechanisms governing scandium dynamics in the critical zone: Geochimica et Cosmochimica Acta 260, 292-310. https://doi.org/10.1016/j. gca.2019.06.036

Colin, F., Nahon, D., Trescases, J.J., Melfi, A.J., 1990, Lateritic weathering of pyroxenites at Niquelandia, Goias, Brazil - The supergene behavior of nickel: Economic Geology, 85, 1010-1023. https://doi.org/10.2113/ gsecongeo.85.5.1010

Domènech, C., Galí, S., Villanova-de-Benavent, C., Soler, J.M., Proenza, J.A., 2017, Reactive transport model of the formation of oxidetype Ni-laterite profiles (Punta Gorda, Moa Bay, Cuba): Mineralium Deposita, 52, 993-1010. https://doi.org/10.1007/ s00126-017-0713-0
Dublet, G., Juillot, F., Morin, G., Fritsch, E., Fandeur, D., Brown, Jr, G.E., 2015, Goethite aging explains $\mathrm{Ni}$ depletion in upper units of ultramafic lateritic ores from New Caledonia: Geochimica et Cosmochimica Acta, 160, 1-15. https://doi.org/10.1016/j. gca.2015.03.015

Dublet, G., Juillot, F., Brest, J., Noe, V., Fritsch, E., Proux, O., Olivi, L., Loquin, F., Morin, G., 2017, Vertical changes of the Co and Mn speciation along a lateritic regolith developed on peridotites (New Caledonia): Geochimica et Cosmochimica Acta, 217, 1-15. https:// doi.org/10.1016/j.gca.2017.07.010

Eliopoulos, D.G., Economou-Eliopoulos, M., 2000, Geochemical and mineralogical characteristics of $\mathrm{Fe}-\mathrm{Ni}$ and bauxitic-laterite deposits of Greece: Ore Geology Reviews, 16, 41-58. https://doi.org/10.1016/ S0169-1368(00)00003-2

Freyssinet, P., Butt, C.R.M., Morris, R.C., Piantone, P., 2005, Ore-forming processes related to lateritic weathering: Economic Geology, 100, 681-722. https://doi. org/10.5382/AV100.21

Galí S., Soler J.M., Proenza J.A., Lewis J.F., Cama J., Tauler E., 2012, Ni-enrichment and stability of Al-free garnierite solid-solutions: A thermodynamic approach; Clays and Clay Minerals 60, 121-135. https://doi. org/10.1346/CGMN.2012.0600203

Giunta G., Beccaluva, L., Coltorti, M., Mortellaro, D., Siena, F., Gutrupia, D., 2002a, The periCaribbean ophiolites: structure, tectonomagmatic significance and geodynamic implications: Caribbean Journal of Earth Science, 36, 1-20.

Giunta G., Beccaluva, L., Coltorti, M., Siena, F., Vaccaro, C., 2002b, The southern margin of the Caribbean Plate in Venezuela: tectono-magmatic setting of the ophiolitic units and kinematic evolution: Lithos, 63, 19-40. https://doi.org/10.1016/ S0024-4937(02)00120-2

Gleeson, S.A., Butt, G.R., Elias, M., 2003: Nickel laterites: a review: Society for Economic Geologists Newsletter, 54, 11-18. 
Gleeson, S.A., Herrington, R.J., Durango, J., Velásquez, C.A., Koll, G., 2004, The mineralogy and geochemistry of the Cerro Matoso S.A. Ni laterite deposit, Montelíbano, Colombia: Economic Geology, 99, 11971213. ttps://doi.org/10.2113/99.6.1197

Golightly, J.P., 1981, Nickeliferous laterite deposits: Economic Geology, 75th anniversary volume, 710-735. https://doi.org/10.5382/AV75.18

Golightly, J.P., 2010, Progress in understanding the evolution of nickel laterites: Society Economic Geology Special Publication 15, 451-485. https://doi.org/10.5382/ SP.15.2.07

Golightly, J.P., Arancibia, O.N., 1979, The chemical composition and infrared spectrum of nickel- and iron-substituted serpentine form a nickeliferous laterite profile, Soroako, Indonesia: Canadian Mineralogist 17, 719-728.

Hackley, P., Urbani, F., Karlsen, A., Garrity, C., 2006, Mapa Geológico de Venezuela a Escala 1: 750,000, U.S. Geological Survey Open File Report 2006-1 109, versión 1.0.

Kuck, P.H., 2013, Nickel. U.S. Geological Survey Mineral Commodities summaries 108-109.

Lambiv Dzemua, G., Gleeson, S.A., Schofield, P.F., 2013, Mineralogical characterization of the Nkamouna Co-Mn laterite ore, southeast Cameroon: Mineralium Deposita, 48, 155-171. https://doi.org/10.1007/ s00126-012-0426-3.

Levard, C., Borschneck, D., Grauby, O., Rose, J., Ambrosi, J.P., 2018, Goethite, a TailorMade Host for the Critical Metal Scandium: the $\mathrm{FexSc}(1-\mathrm{x}) \mathrm{OOH}$ Solid Solution. Geochemical Perspectives Letters, 9, 16-20. https://doi.org/10.7185/geochemlet.1832

Lewis, J., Draper, G., Proenza, J., Espaillat, J., Jiménez,J., 2006, Ophiolite-related ultramafic rocks (serpentinites) in the Caribbean region: a review of their occurrence, composition, origin, emplacement and nickel laterite soils formation: Geologica Acta, 4, 1-2, 237-263. https://doi.org/10.1344/105.000000368
Llorca, S., Monchoux, P., 1991, Supergene cobalt minerals from New Caledonia: Canadian Mineralogist, 29, 149-16.

McRae, M.E., 2018, Nickel. U.S. Geological Survey Mineral Commodities summaries, 111-112.

Mongelli, G., Boni, M., Buccione, R., Sinisi, R., 2014, Geochemistry of the Apulian karst bauxites (southern Italy): chemical fractionation and parental affinities: Ore Geology Reviews, 63, 9-21. https://doi. org/10.1016/j.oregeorev.2014.04.012

Ndjigui, P.D., Bilong, P., Bitom, D., Dia, A., 2008, Mobilization and redistribution of major and trace elements in two weathering profiles developed on serpentinites in the Lomié ultramafic complex, SouthEast Cameroon: Journal of African Earth Sciences, 50, 305-325.https: / / doi.org/10.1016/j. jafrearsci.2007.10.006

Ndjigui, P.D., Bilong, P., 2010, Platinum-group elements in the serpentinite lateritic mantles of the Kongo-Nkamouna ultramafic massif (Lomié region, South-East Cameroon): Journal of Geochemical Exploration, 107, 63-76. https://doi.org/10.1016/j. gexplo.2010.06.008

Pelletier, B., 1996, Serpentines in nickel silicate ore from New Caledonia: Australasian Institute of Mining and Metallurgy Publication Series, Nickel Conference, Kalgoorlie (Western Australia), 6/96, 197-205.

Proenza, J.A., 2015, Mineralogía y Geoquímica de Ni, Co, EGP, Sc, REE en Yacimientos Lateríticos: Macla, 20, 3-9.

Putzolu, F., Balassone, G., Boni, M., Maczurad, M., Mondillo, N., Najorka, J., Pirajno, F., 2018, Mineralogical association and Ni-Co deportment in the Wingellina oxide-type laterite deposit (Western Australia): Ore Geology Reviews 97, 21-34. https://doi. org/10.1016/j.oregeorev.2018.05.005

Putzolu, F., Bonis, M., Mondillo, N., Maczurad, M., Piraino, F., 2019, Ni-Co enrichment and High-Tech metals geochemistry in the 
Wingellina Ni-Co oxide-type laterite deposit (Western Australia): Journal of Geochemical Exploration, 196, 282-296. https://doi. org/10.1016/j.gexplo.2018.11.004

Putzolu, F., Abad, I., Balassone, G., Boni, M., Cappelletti, P., Graziano, S. F., Maczurad, M., Mondillo, N., Najorka, J., Santoro, L., 2020, Parent rock and climatic evolution control on the genesis of Ni-bearing clays in Ni-Co laterites: New inferences from the Wingellina deposit (Western Australia): Ore Geology Reviews 120, 103431. https://doi. org/10.1016/j.oregeorev.2020.103431

Roqué-Rosell, J., Mosselmans, J.F.W., Proenza, J.A., Labrador, M., Galí, S., Atkinson, K.D., Quinn, P.D., 2010, Sorption of Ni by "lithiophorite-asbolane" intermediates in Moa Bay lateritic deposits, eastern Cuba: Chemical Geology, 275, 9-18. https://doi. org/10.1016/j.chemgeo.2010.04.006

Roqué-Rosell, J., Villanova-de-Benavent, C., Proenza, J., 2017, The accumulation of $\mathrm{Ni}$ in serpentines and garnierites from the Falcondo Ni-laterite deposit (Dominican Republic) elucidated by means of XAS: Geochimica et Cosmochimica Acta, 198, 48-69. https:// doi.org/10.1016/j.gca.2016.11.004

Sanematsu, K., Watanabe, Y., 2016, Characteristics and Genesis of Ion Adsorption-Type Rare Earth Element Deposits: Reviews in Economic Geology, 18, 55-79. https://doi. org/10.5382/rev.18.03

Soler, J.M., Cama, J., Galí, S., Meléndez, W., Ramírez, A., Estanga, J., 2008, Composition and dissolution kinetics of garnierite from the Loma de Hierro Ni-laterite deposit, Venezuela: Chemical Geology, 249, 191-202. https://doi.org/10.1016/j. chemgeo.2007.12.012

Tauler, E., Lewis, J.F., Villanova-de-Benavent, C., Aiglsperger, T., Proenza, J.A., Domènech, C., Gallardo, T., Longo, F., Galí, S., 2017, Discovery of Ni-smectite rich saprolite at Loma Ortega, Falcondo mining district (Dominican Republic): geochemistry and mineralogy of an unusual case of "hybrid hydrous Mg silicate - clay silicate" type Ni-laterite: Mineralium Deposita, 52, 1011-1030. https://doi.org/10.1007/ s00126-017-0750-8

Teitler, Y., Cathelineau, M., Ulrich, M., Ambrosi, J.P., Munoz, M., Sevin, B., 2019, Petrology and geochemistry of scandium in New Caledonian Ni-Co laterites: Journal of Geochemical Exploration, 196, 131-155. https://doi.org/10.1016/j. gexplo.2018.10.009

Ulrich M., Cathelineau M., Munoz M., Boiron M.-C., Teitler Y., Karpoff A.-M., 2019 The relative distribution of critical (Sc, REE) and transition metals (Ni Co, Cr, Mn, V) in some $\mathrm{Ni}$ laterite deposits of New Caledonia: J. Geochem. Explor. 197, 93-113. https://doi. org/10.1016/j.gexplo.2018.11.017

Urbani, F., 2005, Nomenclatura y síntesis de las Unidades ígneo-metamórficas de la Cordillera de la Costa Venezuela, I Jornadas de Geología de Rocas Ígneas y Metamórficas: Geos, 38, 41-42.

Villanova-de-Benavent, G., Proenza, J.A., Galí, S., García-Casco, A., Tauler, E., Lewis, J.F., Longo, F., 2014, Garnierites and garnierites: textures, mineralogy and geochemistry of garnierites in the Falcondo Ni-laterite deposit, Dominican Republic: Ore Geology Reviews, 58, 91-109. https://doi.org/10.1016/j. oregeorev.2013.10.008

Villanova-de-Benavent, C., Nieto, F., Vitti, C., Proenza, J.A., Galí, S. and Roqué-Rosell, J., 2016, Ni-phyllosilicates (garnierites) from the Falcondo Ni-laterite deposit (Dominican Republic): Mineralogy, nanotextures, and formation mechanism by HRTEM and AEM: American Mineralogist, 101, 1460-1473. https://doi.org/10.2138/am-2016-5518

Villanova-de-Benavent, C., Domènech, G., Tauler, E., Galí, S., Tassara, S. and Proenza, J.A., 2017, Fe-Ni-bearing serpentines from the saprolite horizon of Caribbean Ni-laterite deposits: new insights from thermodynamic 
calculations: Mineralium Deposita, 52, 979-992. https://doi.org/10.1007/ s00126-016-0683-7

Vind, J., Malfliet, A., Bonomi, C., Paiste, P., Sajó, I.E., Blanpain, B., Tkaczyk, A.H., Vassiliadou, V., Panias, D., 2018, Modes of occurrences of scandium in Greek bauxite and bauxite residue: Minerals Engineering 123, 35-48.

Wells, M.A., Ramanaidou, E.R., Verrall, M., Tessarolo, C., 2009, Mineralogy and crystal chemistry of garnierites in the Goro lateritic nickel deposit, New Caledonia: Eur J Miner 21:467-483. 